Prepared in cooperation with the

Connecticut Department of Energy and Environmental Protection

\title{
Nutrient Concentrations and Loads and Escherichia coli Densities in Tributaries of the Niantic River Estuary, Southeastern Connecticut, 2005 and 2008-2011
}

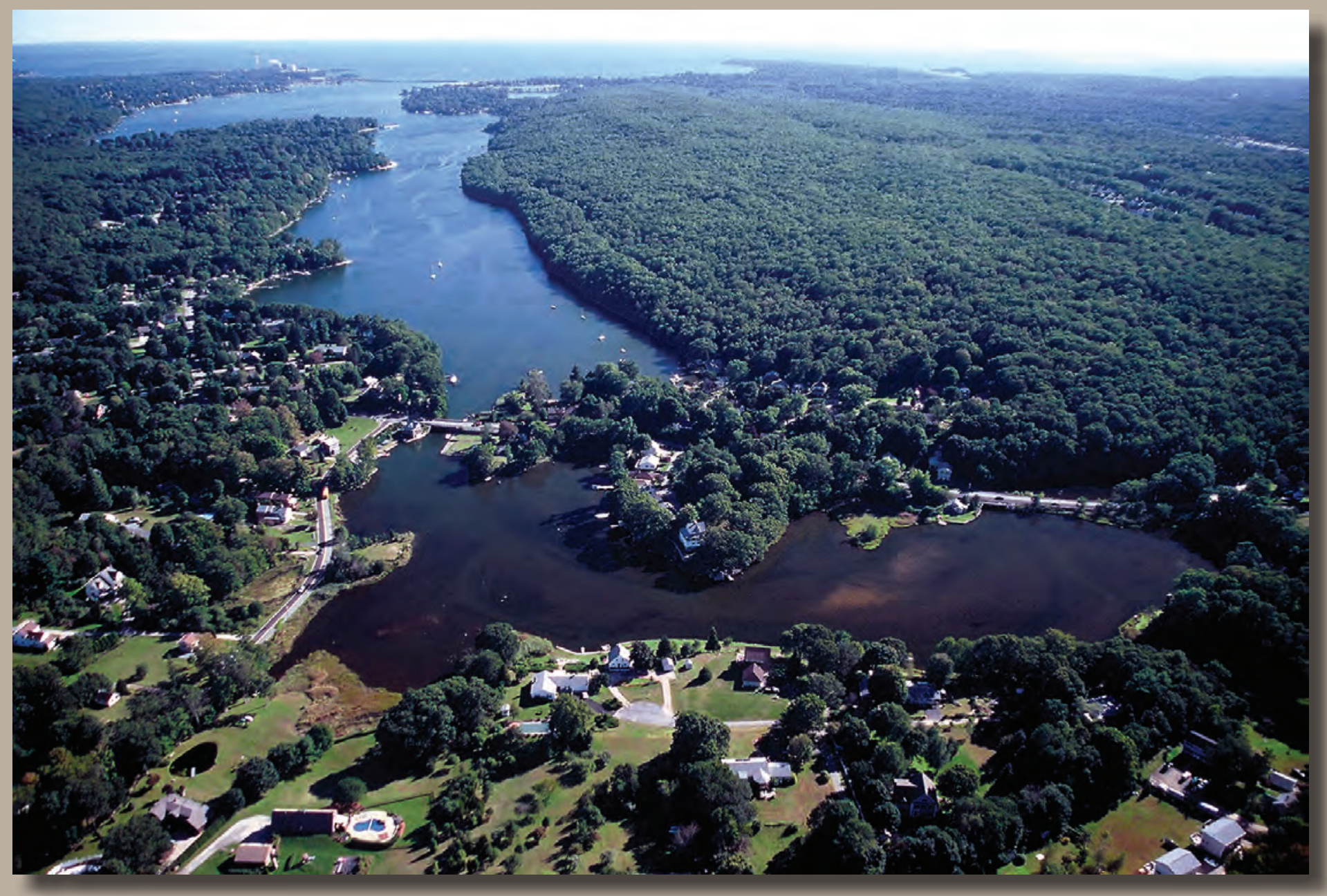

Scientific Investigations Report 2013-5008

U.S. Department of the Interior

U.S. Geological Survey 
Cover. Photograph of the Niantic River, southeastern Connecticut, looking south toward Long Island Sound. The tributaries of Latimer Brook (right) and Oil Mill Brook (left) discharge to the estuary near the bottom of the photo. Courtesy of the Office of Long Island Sound Programs (OSLIP), Bureau of Water Protection and Land Reuse (WPLR), Connecticut Department of Energy and Environmental Protection (CT DEEP). 


\section{Nutrient Concentrations and Loads and Escherichia coli Densities in Tributaries of the Niantic River Estuary, Southeastern Connecticut, 2005 and 2008-2011}

By John R. Mullaney

Prepared in cooperation with the Connecticut Department of Energy and Environmental Protection

Scientific Investigations Report 2013-5008 


\title{
U.S. Department of the Interior \\ KEN SALAZAR, Secretary
}

\section{U.S. Geological Survey \\ Suzette M. Kimball, Acting Director}

\author{
U.S. Geological Survey, Reston, Virginia: 2013
}

For more information on the USGS - the Federal source for science about the Earth, its natural and living resources, natural hazards, and the environment, visit http://www.usgs.gov or call 1-888-ASK-USGS.

For an overview of USGS information products, including maps, imagery, and publications, visit http://www.usgs.gov/pubprod

To order this and other USGS information products, visit http://store.usgs.gov

Any use of trade, firm, or product names is for descriptive purposes only and does not imply endorsement by the U.S. Government.

Although this information product, for the most part, is in the public domain, it also may contain copyrighted materials as noted in the text. Permission to reproduce copyrighted items must be secured from the copyright owner.

Suggested citation:

Mullaney, J.R., 2013, Nutrient concentrations and loads and Escherichia coli densities in tributaries of the Niantic River estuary, southeastern Connecticut, 2005 and 2008-2011: U.S. Geological Survey Scientific Investigations Report 2013-5008, 27 p., http://pubs.usgs.gov/sir/2013/5008/. 


\section{Acknowledgments}

The author would like to thank the following individuals or groups for their assistance: Judy Rondeau and Patricia Young, Niantic River Watershed coordinators; the members of the Niantic River Watershed Committee; Kelly Streich, Eric Thomas, Stan Zaremba, and Paul Stacey, Connecticut Department of Energy and Environmental Protection; and Paul Corrente, Connecticut Department of Transportation. Timothy Frick, Joseph Martin, Guy Holzer, Nicholas Dosch, Michael Colombo, Jason Pollender, and Jonathan Morrison of the U.S. Geological Survey are acknowledged for data collection and analysis. Laura Medalie of the U.S. Geological Survey, and James Latimer of the U.S. Environmental Protection Agency are also thanked for providing technical review of this report. 
This page has been left blank intentionally. 


\section{Contents}

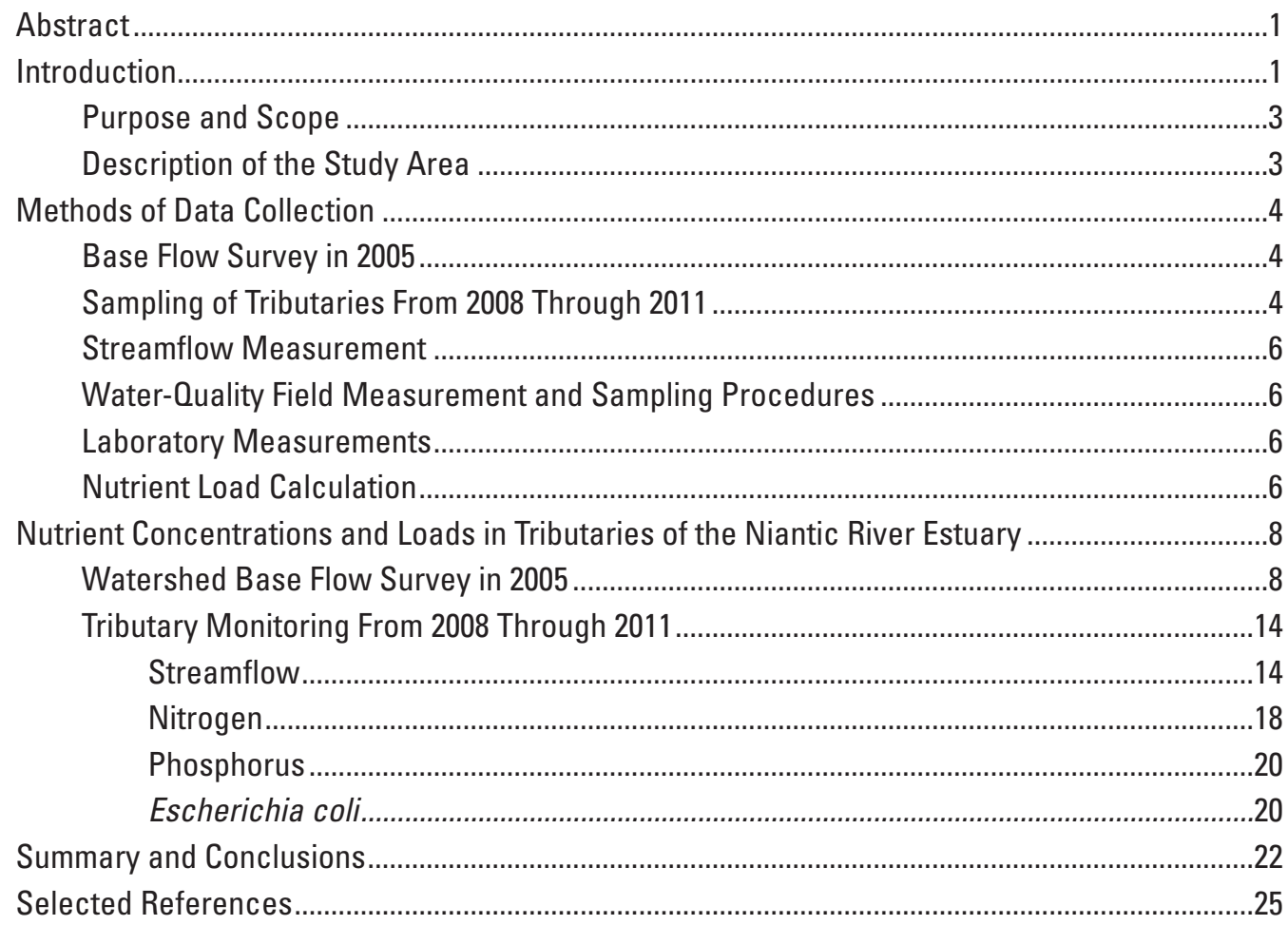

\section{Figures}

1. Map showing the Niantic River Basin in southeastern Connecticut...............................2

2. Map showing land use and land cover in the Niantic River Basin in 2006 .......................5

3. Map showing nitrogen yields from selected basin segments in the Niantic River Basin on June 1-3, 2005 ......................................................................................13

4. Graph showing approximate compositional ranges of $\delta^{15} \mathrm{~N}$ and $\delta^{18} 0$ data for sources of nitrate.

5. Graph showing the instantaneous nitrogen yield by percentage of developed land for basin segments in the Niantic River Basin from water-quality samples and streamflow measurements collected June 1-3, 2005

6. Graphs showing daily discharge from A, Latimer Brook; B, Oil Mill Brook; C, Stony Brook tributaries of the Niantic River, showing dates of samples collected, Niantic River Basin, southeastern Connecticut.

7. Boxplots showing the distribution of total nitrogen concentrations in the Niantic River Basin in southeastern Connecticut from August 2008 through February 2012 ......18

8. Boxplots showing distribution of total ammonia plus organic nitrogen concentrations in the Niantic River Basin in southeastern Connecticut from August 2008 through February 2012.

9. Boxplots showing distribution of total phosphorus concentrations in the Niantic River Basin in southeastern Connecticut from August 2008 through February 2012 .....22 
10. Boxplots showing distribution of Escherichia coli densities in the Niantic River Basin in southeastern Connecticut from August 2008 through February 2012

11. Graphs showing cumulative probability plots of Escherichia coli densities for dry and wet weather samples from October 2008 through September 2011 25

\section{Tables}

1. Land use in the Niantic River Basin in southeastern Connecticut in 2006 .7

2. Analytes for nutrient samples and analytical methods. .8

3. Instantaneous nitrogen concentrations and loads, yields, and isotopic measurements in the Niantic River Basin on June 1-3, 2005

4. Streamflow and total nitrogen loads and yields for 11 basin segments in the Niantic River Basin on June 1-3, 2005

5. Instantaneous phosphorus concentrations and loads and yields in the Niantic River Basin on June 1-3, 2005 ...

6. Streamflow characteristics of three Niantic River tributaries in southeastern Connecticut for water years 2009-2011

7. Summary statistics of selected nitrogen and phosphorus constituents and Escherichia coli for water-quality samples collected at three U.S. Geological Survey streamgages in the Niantic River Basin in southeastern Connecticut from August 2008 through February 2012.

8. Loads and yields of total nitrogen and total ammonia plus organic nitrogen for three stations in the Niantic River Basin in southeastern Connecticut from October 2008 through September 2011

9. Loads and yields of total phosphorus for three U.S. Geological Survey streamgages in the Niantic River Basin in southeastern Connecticut from October 2008 through September 2011 


\section{Conversion Factors and Datum}

\begin{tabular}{|c|c|c|}
\hline Multiply & By & To obtain \\
\hline \multicolumn{3}{|c|}{ Length } \\
\hline foot $(\mathrm{ft})$ & 0.3048 & meter $(\mathrm{m})$ \\
\hline \multicolumn{3}{|c|}{ Area } \\
\hline square mile $\left(\mathrm{mi}^{2}\right)$ & 259.0 & hectare (ha) \\
\hline square mile $\left(\mathrm{mi}^{2}\right)$ & 2.590 & square kilometer $\left(\mathrm{km}^{2}\right)$ \\
\hline \multicolumn{3}{|c|}{ Volume } \\
\hline million gallons (Mgal) & 3,785 & cubic meter $\left(\mathrm{m}^{3}\right)$ \\
\hline cubic foot $\left(\mathrm{ft}^{3}\right)$ & 0.02832 & cubic meter $\left(\mathrm{m}^{3}\right)$ \\
\hline \multicolumn{3}{|c|}{ Flow rate } \\
\hline cubic foot per second $\left(\mathrm{ft}^{3} / \mathrm{s}\right)$ & 0.02832 & cubic meter per second $\left(\mathrm{m}^{3} / \mathrm{s}\right)$ \\
\hline $\begin{array}{l}\text { cubic foot per second per square } \\
\text { mile }\left[\left(\mathrm{ft}^{3} / \mathrm{s}\right) / \mathrm{mi}^{2}\right]\end{array}$ & 0.01093 & $\begin{array}{l}\text { cubic meter per second per square } \\
\text { kilometer }\left[\left(\mathrm{m}^{3} / \mathrm{s}\right) / \mathrm{km}^{2}\right]\end{array}$ \\
\hline million gallons per day (Mgal/d) & 0.04381 & cubic meter per second $\left(\mathrm{m}^{3} / \mathrm{s}\right)$ \\
\hline \multicolumn{3}{|c|}{ Mass } \\
\hline $\begin{array}{l}\text { pounds per square mile per year } \\
{\left[\left(\left(\mathrm{lb} / \mathrm{mi}^{2}\right) \mathrm{yr}\right]\right.}\end{array}$ & 0.001751 & $\begin{array}{l}\text { kilogram per hectare per year } \\
{[(\mathrm{kg} / \mathrm{ha}) / \mathrm{yr}]}\end{array}$ \\
\hline
\end{tabular}

Vertical coordinate information is referenced to the North American Vertical Datum of 1988

(NAVD 88).

Horizontal coordinate information is referenced to the North American Datum of 1983 (NAD 83).

Concentrations of chemical constituents in water are given in milligrams per liter (mg/L).

\section{Abbreviations}

AMLE adjusted maximum likelihood estimation

CTDEEP Connecticut Department of Energy and Environmental Protection

cfu colony-forming units

E. coli Escherichia coli

EWI equal width increment

LISS Long Island Sound study

LOADEST load estimator

MLE maximum likelihood estimation

NWIS National Water Information System

NWQL National Water Quality Laboratory

USGS U.S. Geological Survey

USEPA U.S. Environmental Protection Agency 
viii

This page has been left blank intentionally. 


\title{
Nutrient Concentrations and Loads and Escherichia coli Densities in Tributaries of the Niantic River Estuary, Southeastern Connecticut, 2005 and 2008-2011
}

\author{
By John R. Mullaney
}

\section{Abstract}

Nutrient concentrations and loads and Escherichia coli (E. coli) densities were studied in 2005 and from 2008 through 2011 in water-quality samples from tributaries of the Niantic River Estuary in southeastern Connecticut. Data from a water-quality survey of the base flow of subbasins in the watershed in June 2005 were used to determine the range of total nitrogen concentrations ( 0.09 to 2.4 milligrams per liter), instantaneous loads (less than 1 to 62 pounds per day) and the yields of total nitrogen ranging from 0.02 to 11.2 pounds per square mile per day (less than 1 to 7.2 kilograms per hectare per year) from basin segments. Nitrogen yields were positively correlated with the amount of developed land in each subbasin. Stable isotope measurements of nitrate $\left(\delta^{15} \mathrm{~N}\right)$ and oxygen $\left(\delta^{18} \mathrm{O}\right)$ ranged from 3.9 to 9.4 per mil and 0.7 to 4.1 per mil, respectively, indicating that likely sources of nitrate in base flow are soil nitrate and ammonium fertilizers, sewage or animal waste, or a mixture of these sources.

Continuous streamflow and monthly water-quality sampling, with additional storm event sampling, were conducted at the three major tributaries (Latimer Brook, Oil Mill Brook, and Stony Brook) of the Niantic River from October 2008 through September 2011. Samples were analyzed for nitrogen and phosphorus constituents and $E$. coli densities. Total freshwater discharge from these tributaries, which is reduced by upstream withdrawals, ranged from 25.9 to 37.8 million gallons per day. Total nitrogen and phosphorus concentrations generally were low, with the mean values below the U.S. Environmental Protection Agency recommended nutrient concentration values of 0.71 milligram per liter and 0.031 milligram per liter, respectively. Total nitrogen was predominantly in the form of total ammonia plus organic nitrogen at the Oil Mill Brook and Stony Brook sites and in the form of nitrate at Latimer Brook.

Annual total nitrogen loads that flowed into the Niantic River estuary from the three major tributaries, calculated with the Load Estimator computer program, ranged from 41,400 to 60,700 pounds, with about 52 to 59 percent of the load as total ammonia plus organic nitrogen. Total phosphorus loads ranged from 1,770 to 3,540 pounds per year. Yields of total nitrogen were highest from Latimer Brook, with the range from the three tributaries between 1,100 and 2,720 pounds per square mile per year. Total phosphorus yields ranged from 52 to 185 pounds per square mile per year.

The geometric means of $E$. coli densities in samples from the three Niantic River tributaries were less than the State of Connecticut water-quality standard of 126 colonyforming units per 100 milliliters; however, individual samples from all three tributaries had densities as high as 2,400 to 2,900 colony-forming units per 100 milliliters. High densities of $E$. coli were more likely to be present in samples collected during wet weather events.

\section{Introduction}

The Niantic River is an estuary at the mouth of a developed 30.2-square-mile $\left(\mathrm{mi}^{2}\right)$ coastal basin in southeastern Connecticut on Long Island Sound (fig. 1). The eelgrass beds of the Niantic River function as a nursery ground and feeding ground for a number of recreationally and commercially important bird, shellfish and finfish species. Many people enjoy the recreational opportunities afforded by the river, including boating, kayaking, sailing, swimming, fishing, and shellfishing. While the Niantic continues to serve all these functions, it has experienced fluctuations in water quality during the past few decades. The river once supported a major recreational scallop fishery, which has declined drastically. Episodic summertime hypoxia events in deeper bottom waters of the upper estuary have occurred occasionally.

During the past two decades, point source nutrient loads associated with failing privately maintained onsite septic systems have been ameliorated along most of the developed shoreline of the Niantic River through the installation of municipal sewer systems. These controls have resulted in measurable improvements in the Niantic River. For example, eelgrass distribution and abundance have increased dramatically, and for the first time in more than two decades, winter 2011-12 was a very successful scallop season. 


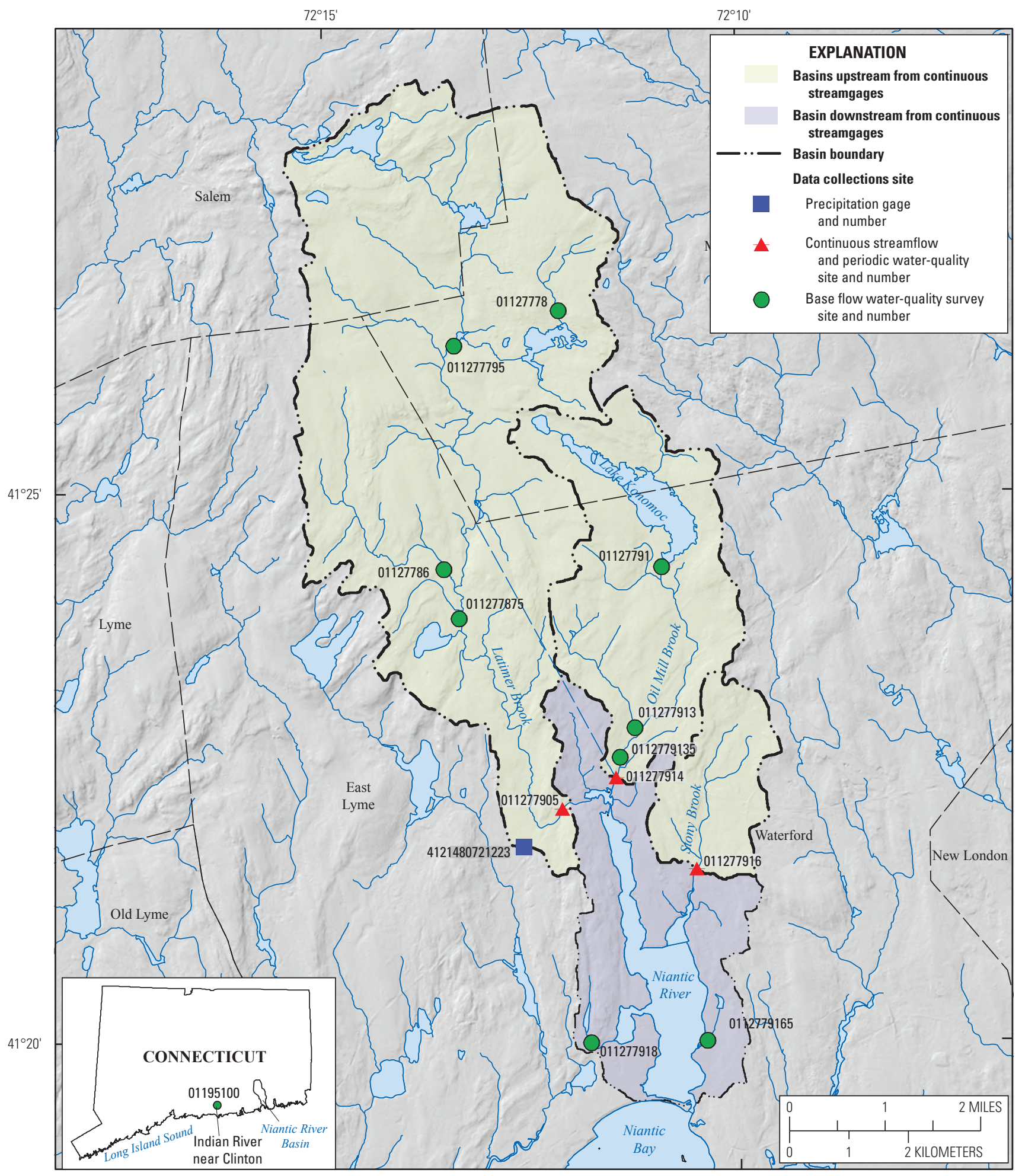

Base from University of Connecticut, Department of Agriculture and Natural Resources, 2000 NAD83 Lambert Conformal Conic projection

Figure 1. The Niantic River Basin in southeastern Connecticut. The locations of U.S. Geological Survey (USGS) water-quality monitoring sites and streamgages in tributaries of the Niantic River Estuary are shown. NAD83, North American Datum of 1983. 
The presence of so-called "nuisance" macroalgae indicates that nitrogen loads are relatively high, though currently low enough to provide a suitable environment for eelgrass (Jamie Vaudrey, professor, University of Connecticut, written commun., April 2012). Excessive nitrogen loading to the Niantic River is considered to be a major cause of decline and variability of eelgrass populations (Connecticut Department of Environmental Protection, 2006). Currently, the Niantic River is the first embayment where eelgrass is present in Long Island Sound, when moving from west (New York City area) to east, along a gradient of improving water quality. Therefore, the Niantic River is currently thought to have marginal water quality with respect to eelgrass habitat. There is concern that, with increasing development in the watershed, the Niantic River will not be able to support eelgrass habitats in the future.

The Long Island Sound Study (LISS) began in 1985 under the sponsorship of the U.S. Environmental Protection Agency (USEPA) and the States of Connecticut and New York to protect and restore the health of Long Island Sound.

The Connecticut Department of Energy and Environmental Protection (CTDEEP) and LISS are interested in improving eelgrass habitats and expanding the areas of suitable eelgrass habitat. In addition, research has been conducted to determine requirements to protect or improve eelgrass habitats in Long Island Sound (Vaudrey, 2008). The development of nutrient requirements for estuaries is complicated by the mixing of freshwater from tributaries and groundwater with saltwater from the ocean. The factors affecting optimal nutrient concentrations for eelgrass include the size of the watershed area relative to the area of the estuary, the volume of the tidal prism, the quality of marine water entering from outside the estuary, and additional factors.

The CTDEEP has listed the Niantic River on the impaired waters list of the State of Connecticut (Clean Water Act, secs. $303 \mathrm{~b}$ and $305 \mathrm{~b}, 33$ U.S.C. $\S \S 1313$ and 1315); the river is considered to be impaired for habitat for marine fish, other aquatic life, and wildlife. The listed potential cause for this impairment includes eutrophication resulting from nutrients with sources such as flow alterations from water diversions, urban stormwater, on-vessel discharges, and residential land use (Connecticut Department of Environmental Protection, 2011a, table 3-2).

The Niantic River also has been listed as impaired for shellfish harvesting due to the presence of excess fecal coliform bacteria, with sources ranging from urban stormwater, on-vessel discharges, onsite wastewater treatment systems, residential areas, and waterfowl. The lower reaches of the three major Niantic River tributaries also are listed as impaired by Escherichia coli (E. coli) bacteria (Connecticut Department of Environmental Protection, 2011a, table 3-2).

In 2006, the Niantic River watershed protection plan (Connecticut Department of Environmental Protection, 2006) was developed with recommendations to improve water quality throughout the watershed, eliminate shellfish bed closures, support fish and wildlife habitat, and provide safe and healthy recreational areas. Among the recommendations was monitoring of the Niantic River tributaries to provide baseline data on nutrients and bacteria to be compared with future conditions after management measures have been implemented.

An understanding of the river discharge and quantity and source of nutrients entering the Niantic River from the tributaries of the river is essential for establishing nutrient criteria for eelgrass survival. In addition, accurate information on the tributary loads of nutrients is required for understanding the mass balance and sources of nutrients in the watershed so the loads can be effectively managed. Data on indicator bacteria are necessary to provide baseline information to be compared with future data once management measures are in place to resolve the impairments.

To provide baseline data on the nutrient budget and the distribution of indicator bacteria, the U.S. Geological Survey (USGS) and the CTDEEP conducted cooperative studies in 2005 and from 2008 through 2011 in the Niantic River Basin.

\section{Purpose and Scope}

This report provides information on the concentrations, loads, and yields of nitrogen and phosphorus in subbasins of the Niantic River. Data and data analysis are summarized from a basinwide base flow water-quality survey of nutrients from June 1-3, 2005, and includes nitrogen isotope composition of nitrate to assist with identifying sources of nitrogen. Data are presented on instantaneous streamflows and loads of nitrogen from 11 subbasins of the Niantic River.

The main focus of the report is on streamflow, nutrient, and indicator bacteria data from the three major tributaries of the Niantic River for the period October 2008 through February 2012. Data from this time period were used to develop statistical summaries of concentration and bacteria density. Data for water quality and streamflow from October 2008 through September 2011 (water years ${ }^{1}$ 2009-2011) were used to calculate annual loads and yields of nitrogen and phosphorus.

\section{Description of the Study Area}

The Niantic River Basin is in coastal southeastern Connecticut, draining an area of $30.2 \mathrm{mi}^{2}$, and lies between the Connecticut River Basin on the west and the Thames River Basin on the east. The Niantic River estuary is primarily a saltwater environment that covers an area of $1.25 \mathrm{mi}^{2}$ at the mouth of the basin. The three largest tributaries contributing fresh water to the Niantic River estuary are Latimer Brook, Oil Mill Brook, and Stony Brook (fig. 1).

\footnotetext{
${ }^{1} \mathrm{~A}$ water year is the period between October 1 of the previous year through September 30 of the year designated; for example, water year 2009 covers October 1, 2008, through September 30, 2009.
} 
Land surface ranges from sea level near the mouth of the estuary to about 600 feet above the North American Vertical Datum of 1988 (NAVD88) in the headwaters in the town of Montville. Land cover and land use (University of Connecticut, 2009) in the watershed (fig. 2) is about 61 percent forest, about 18 percent developed land, including turf, 5 percent wetlands, and 3.3 percent agricultural areas. The remaining 12.7 percent of the watershed contains areas with water, other grasses, barren land, and utility rights of way. About 12 percent of the watershed is in sewer service areas; not all areas within sewer service districts had sewers in 2012. Wastewater from the sewers is delivered to the sewage treatment system for the city of New London outside the Niantic River Basin and is discharged to the Thames River. The total population of the Niantic River Basin was about 8,500 in 2000 and 10,200 in 2010, based on a spatial analysis overlay of U.S. Census Bureau blocks with the basin boundaries (U.S. Census Bureau, 2012).

The surficial geology of the Niantic River Basin includes deposits of glacial till of varying thickness underlying 75 percent of the watershed and coarse-grained glacial stratified deposits underlying 17 percent of the watershed, primarily in the river and stream valleys (Stone and others, 1992). The remaining land area is underlain by fine-grained glaciolacustrine and swamp deposits. The surficial geology controls whether groundwater discharge or overland runoff is the dominant source of water and nutrients in different regions of the basin. Areas with coarse-grained glacial stratified deposits have higher groundwater recharge rates than areas with glacial till and consequently provide an important source of stream base flow (Thomas, 1966).

\section{Methods of Data Collection}

Data collected in June 2005 for the first phase of this project included surface water-quality samples that were collected, during typical base flows, and were analyzed for nitrogen concentrations. Instantaneous streamflow was measured at the time of sample collection to determine loads of nitrogen representative of groundwater discharge in selected parts of the Niantic River Basin. Data were used to determine which regions of the watershed had the largest yields of nitrogen. Water-quality samples were analyzed for nitrogen isotopes as a means identifying dominant sources of nitrate nitrogen.

For the second phase of the project, water-quality samples and continuous streamflow data were collected from 2008 through 2012 at stations near the mouths of the three largest tributaries of the Niantic River-Latimer Brook, Oil Mill Brook, and Stony Brook. Samples were analyzed for concentrations of nutrients and densities of $E$. coli bacteria.

\section{Base Flow Survey in 2005}

A survey of base flow water quality was conducted in 2005 to make initial estimates of the nutrient loads to Niantic River tributaries from groundwater discharge in different parts of the Niantic River Basin. Sites were selected at 11 locations (fig. 1; table 1) in the watershed for water-quality sampling and streamflow measurement.

Ideally, sampling would be designed to occur at a time when groundwater levels and stream base flows in the region were as close as possible to the long-term average. Data from the nearby long-term streamgage at the Indian River in Clinton (USGS streamgage 01195100; fig. 1, inset map) were examined to determine when conditions were similar to longterm average base flows. The base flow separation program PART (Rutledge, 1998) was used to analyze streamflow data from the Indian River streamgage collected from 1982 through 2003 and estimate the long-term average base flow. The mean base flow from this period was estimated to be 6.6 cubic feet per second $\left(\mathrm{ft}^{3} / \mathrm{s}\right)$. Samples were collected in the Niantic River Basin when the flow at the Indian River in Clinton was 3.0 to $3.3 \mathrm{ft}^{3} / \mathrm{s}$, indicating that base flows were about half the longterm average conditions. Therefore, loads estimated for this study may be lower than average.

Sampling was conducted during a dry 3-day period (June 1-3, 2005) to minimize change in streamflows during sampling. Samples were collected and analyzed for nitrogen and phosphorus constituents and for nitrogen 15-to-nitrogen 14 ratio of nitrogen in nitrate $\left(\delta^{15} \mathrm{~N}\right.$ of $\left.\mathrm{NO}_{3}\right)$ and oxygen 18-to-oxygen 16 ratio of oxygen in nitrate $\left(\delta^{18} \mathrm{O}\right.$ of $\left.\mathrm{NO}_{3}\right)$. The nitrogen and oxygen isotopes were used to assist in determining the sources of nitrate in base flow to the tributaries of the basin.

Water-quality concentrations and instantaneous streamflow measurements were used to calculate instantaneous loads of total nitrogen and total phosphorus at each monitoring site. Load estimates were converted to estimates of nutrient yields to compare among subbasins. Loads for the watersheds of selected reaches were calculated by subtracting loads at the upstream monitoring sites from the loads at downstream locations. Yield was then calculated by dividing the instantaneous load (or gain in instantaneous load) by the drainage area in the selected reach.

\section{Sampling of Tributaries From 2008 Through 2011}

To determine continuous stream stage and discharge and to calculate the loads of nitrogen and phosphorus and densities of $E$. coli bacteria, streamgages were established on the three major tributaries of the Niantic River (fig. 1; table 1) during summer 2008. Water-quality samples were collected monthly at these sites and analyzed for nitrogen and phosphorus constituents and E. coli densities. Additional 


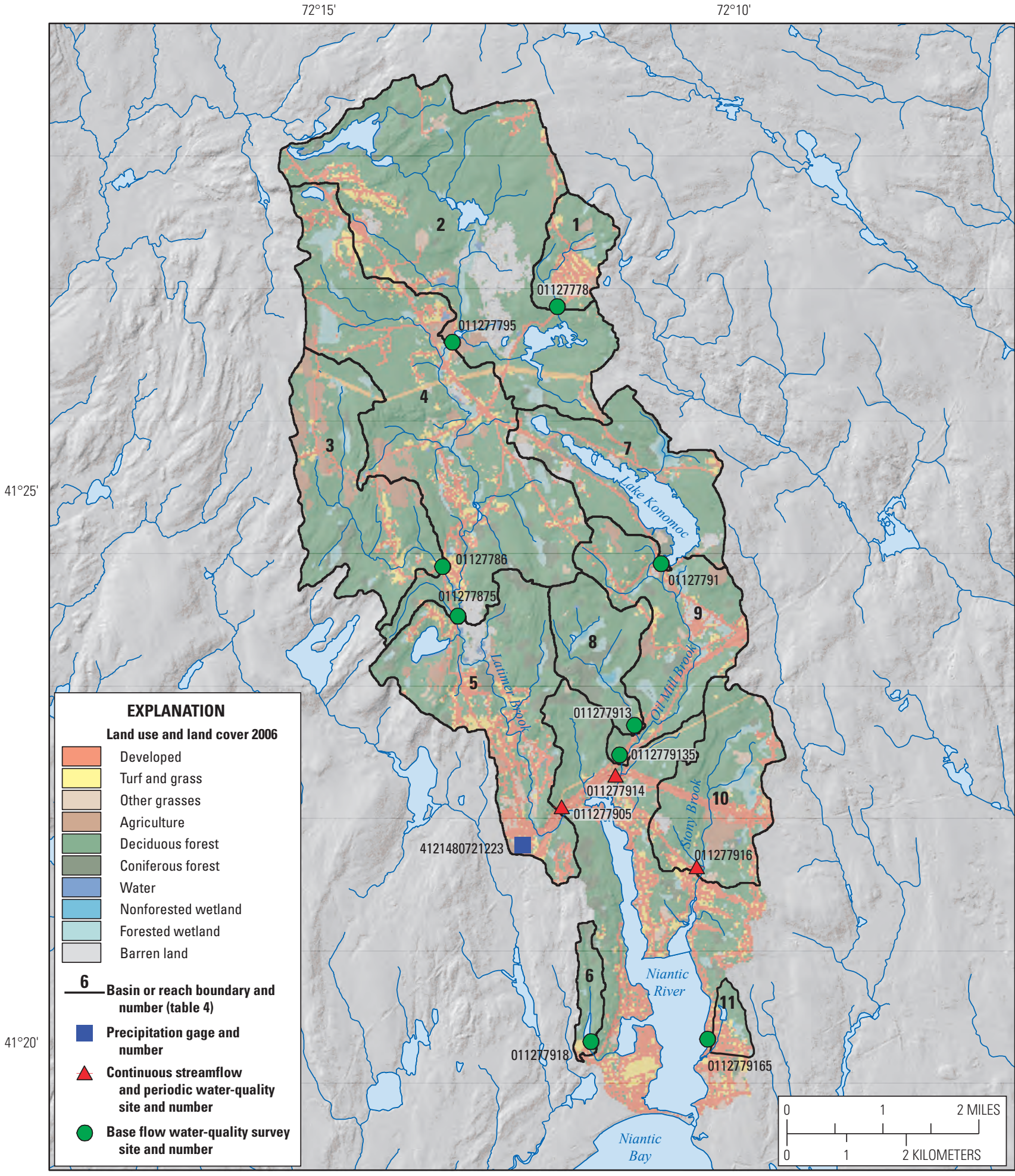

Base from University of Connecticut, Department of Agriculture and Natural Resources, 2000 NAD83 Lambert Conformal Conic projection

Land use and land cover data from University of Connecticut, 2009 Center for Land Use Education and Research

Figure 2. Land use and land cover in the Niantic River Basin, southeastern Connecticut, in 2006. NAD83, North American Datum of 1983; USGS, U.S. Geological Survey. 
samples were collected during three storm and high-flow events in water years 2009 and 2010 to better define the relation between nutrient constituent concentrations and a range of streamflows. Annual loads of nutrient constituents were determined for water years 2009 through 2011. Field measurements of specific conductance, $\mathrm{pH}$, dissolved oxygen, water temperature, and turbidity were made for every sample that was collected.

\section{Streamflow Measurement}

As part of the base flow water-quality survey, instantaneous streamflow measurements were made at selected sites in 2005. After the streamgages were established on Latimer Brook, Oil Mill Brook, and Stony Brook in 2008 (fig. 1), streamflow measurements were made to develop and maintain stage-to-discharge rating curves for each site. Stage data were collected at 15 -minute intervals at Latimer Brook and 5-minute intervals at Oil Mill Brook and Stony Brook. These stage data were used in conjunction with the rating curves to develop a record of continuous streamflow for each streamgage.

Streamflow measurements and discharge computations until 2010 were done following the procedures described in Rantz (1982a,b); after 2010, the methods were supplemented using techniques in Sauer and Turnipseed (2010) and Turnipseed and Sauer (2010).

\section{Water-Quality Field Measurement and Sampling Procedures}

Water-quality sample collection methods and equipment selection for this study are described in Wilde and others (1998a-c, 1999a,b). Sampling methods depended on the flow conditions. In high-flow conditions, samples were collected using an equal width increment (EWI) method, compositing samples from at least 10 equally spaced locations across the stream channel. In low-flow conditions, samples were collected using a single vertical in the channel thalweg. Field measurements were made during each site visit and included specific conductance, temperature, $\mathrm{pH}$, dissolved oxygen, and turbidity. The methods are described in Wilde and Radtke (1998). Water-quality samples for nutrient analyses were preserved as needed and stored on ice before shipping within 3 days to the USGS National Water Quality Laboratory (NWQL) in Denver, Colorado.

Water-quality samples also were collected from Latimer Brook, Oil Mill Brook, and Stony Brook to determine E. coli bacteria densities. The samples were collected, processed, and analyzed by USGS field personnel using standard sampling procedures outlined by the Connecticut Department of Public Health and Connecticut Department of Environmental Protection (2003).

\section{Laboratory Measurements}

Table 2 lists the methods used to analyze samples for nitrogen and phosphorus species at the NWQL. Analytical results were entered into the National Water Information System (NWIS) database by laboratory personnel. Total nitrogen was calculated as the sum of total ammonia plus organic nitrogen and nitrite plus nitrate nitrogen.

Subsamples collected during the watershed base flow survey in 2005 also were analyzed for the $\delta^{15} \mathrm{~N}$ of $\mathrm{NO}_{3}$ and $\delta^{18} \mathrm{O}$ of $\mathrm{NO}_{3}$. Analysis for these isotopes required a concentration of at least 0.03 milligram per liter $(\mathrm{mg} / \mathrm{L})$ of nitrate as $\mathrm{N}$ and a total mass of $0.002 \mathrm{mg}$ of nitrate as $\mathrm{N}$ in the sample. Samples were analyzed at the USGS Stable Isotope Laboratory in Reston, Virginia, using the methods in Coplen and others (2004).

\section{Nutrient Load Calculation}

Nutrient loads were calculated for data collected in 2005 and from 2008 through 2011. Instantaneous nitrogen loads were calculated for the sites sampled during the 2005 base flow survey by multiplying the constituent concentration by the instantaneous flow and converting to appropriate units. Using data collected from 2008 through 2011, annual nutrient loads for nitrogen and phosphorus constituents were determined for the three Niantic River tributaries using the Load Estimator (LOADEST) computer program (Runkel and others, 2004). Given a time series of daily streamflow and instantaneous constituent concentration, LOADEST assists the user in developing a regression model for the estimation of constituent load. Explanatory variables in the regression model may include various functions of streamflow, decimal time, seasonal terms, and additional user-specified data. The formulated regression model then is used to estimate loads over a user-specified time interval.

Load estimations for this project used adjusted maximum likelihood estimation (AMLE; Cohn, 1988; Cohn and others, 1992) because the dataset contained censored data (below an analytical or reporting threshold). Retransformation bias (underestimation of true loads resulting from changing estimates made in log space back to actual numbers) is handled in the AMLE by equations specially designed for censored data. Load estimations using datasets with no censored data converge to the Maximum Likelihood Estimation (MLE); either estimation method, used appropriately, results in a minimum-variance, unbiased estimate of constituent loads (Runkel and others, 2004).

Estimations using the AMLE or MLE require that model residuals are normally distributed. As part of the evaluation of models, plots of residuals were analyzed graphically to verify that residuals met or nearly met normality assumptions. 


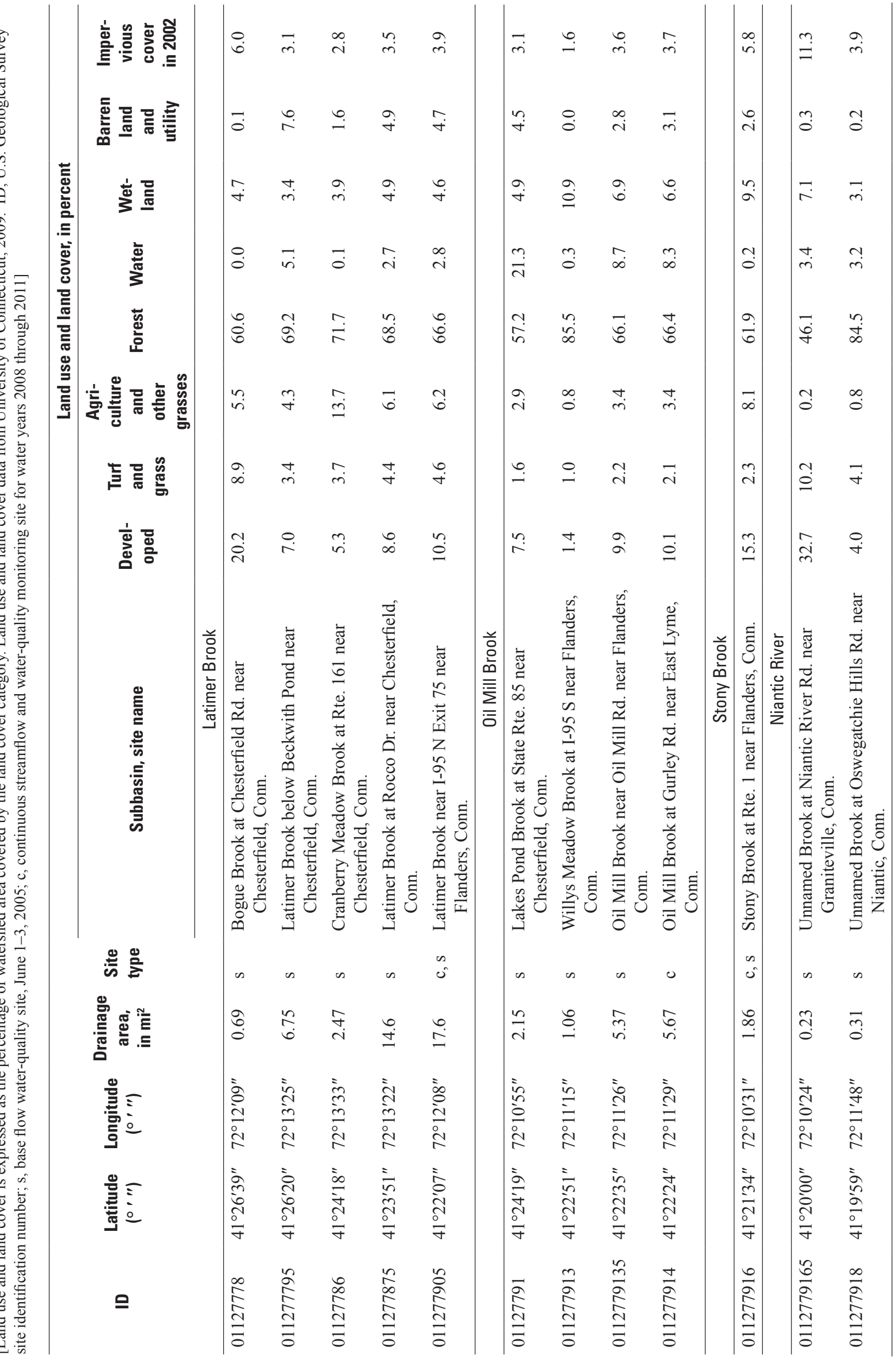


Table 2. Analytes for nutrient samples and analytical methods.

\begin{tabular}{lcl}
\hline \multicolumn{1}{c}{ Analyte } & $\begin{array}{c}\text { Reporting limit, } \\
\text { in milligrams per liter }\end{array}$ & \multicolumn{1}{c}{ Reference to methodology } \\
\hline Nitrogen, ammonia & 0.01 & Fishman (1993) \\
Nitrogen, ammonia plus organic, total & 0.07 & Patton and Truitt (2000) \\
Nitrogen, ammonia and organic, dissolved & 0.07 & Patton and Truitt (2000) \\
Nitrogen, nitrite & 0.001 & Fishman (1993) \\
Nitrogen, nitrite and nitrate & 0.04 & Patton and Kryskalla (2011), Fishman (1993) \\
Phosphorus, dissolved & 0.003 & U.S. Environmental Protection Agency (1993) \\
Phosphorus, phosphate, ortho & 0.004 & Fishman (1993) \\
Phosphorus, total & 0.004 & U.S. Environmental Protection Agency (1993) \\
\hline
\end{tabular}

\section{Nutrient Concentrations and Loads in Tributaries of the Niantic River Estuary}

Instantaneous loads of nutrients were calculated for 11 monitoring stations sampled in June 2005, and isotopic analyses of nitrate were compared with known sources of nitrogen for 9 monitoring stations (table 3). Yields of nitrogen during the base flow survey were calculated for reaches of streams between monitoring stations in the Niantic River Basin and compared by differences in land use (table 4).

Data on nutrient concentrations and streamflows collected from August 2008 through February 2012 were analyzed to determine statistical distributions. They also were compared to USEPA recommended criteria for nitrogen and phosphorus concentrations in streams (U.S. Environmental Protection Agency, 2000). Annual loads and yields of total nitrogen and phosphorus, ammonia plus organic nitrogen, and dissolved phosphorus were calculated for water years 2009 through 2011. E. coli densities were analyzed for waterquality samples collected from August 2008 through February 2011 and compared with State of Connecticut water-quality standards. E. coli densities for samples collected from wet weather events and during dry weather for water years 2008 through 2011 were compared.

\section{Watershed Base Flow Survey in 2005}

Instantaneous streamflow from the subbasins of the Niantic River during June 1-3, 2005, ranged from 0.09 $\mathrm{ft}^{3} / \mathrm{s}$ at Lakes Pond Brook (site 01127791; fig. 1) to $16 \mathrm{ft}^{3} / \mathrm{s}$ at Latimer Brook (site 011277905; fig. 1; tables 3 and 5). Flows generally increased downstream; however, flows in Latimer Brook and Oil Mill Brook are probably lower than expected due to diversions from upstream reservoirs serving the city of New London. To understand the increase in flow due to groundwater discharge, gains in streamflow were calculated by subtracting the flows of upstream stations from downstream stations in the same subbasin. Gains in streamflow (table 4), which represent groundwater inflow, ranged from 0.04 to 2.25 cubic feet per second per square mile $\left(\mathrm{ft}^{3} / \mathrm{s} / \mathrm{mi}^{2}\right.$; table 4$)$ with the smallest discharge per unit area immediately downstream of reservoirs (site 01127791 at the outlet of Lake Konomoc). The largest discharge per unit area was measured in the lower part of the Oil Mill Brook Basin (basin segment 9; fig. 3). Gains in discharge per unit area were largest in segments dominated by coarse-grained glacial stratified deposits.

Total nitrogen concentrations ranged from 0.09 to $2.4 \mathrm{mg} / \mathrm{L}$ (table 3 ). Total nitrogen concentrations included total ammonia plus organic nitrogen, which ranged from less than 0.09 to $0.27 \mathrm{mg} / 1$, and nitrite plus nitrate nitrogen, which ranged from less than 0.06 to $2.0 \mathrm{mg} / \mathrm{L}$. Samples from two locations did not have sufficient nitrate for isotopic analysis. Isotopic results for the remaining nine samples were overlain on a plot (fig. 4) of estimated compositions from different sources, including atmospheric deposition, synthetic nitrate fertilizers, soil nitrate and ammonium fertilizers, and sewage and animal wastes (Ging and others, 1996). Values of $\delta^{15} \mathrm{~N}$ and $\delta^{18} \mathrm{O}$ in nitrate ranged from 3.92 to 9.43 per mil and 0.74 to 4.1 per mil, respectively. Values from eight of the samples from the base flow survey plotted near the estimated compositions for soil nitrate and ammonium fertilizers, and one sample plotted within the range expected for sewage and animal wastes. Therefore, the likely sources of nitrogen from base flow samples in the Niantic River Basin are fertilizer, soil nitrate, and sewage or animal wastewater sources, or some combination. Samples from this survey do not show evidence of atmospheric sources or nitrate that has been subject to denitrification; nitrate from atmospheric deposition tends to have high values of $\delta^{18} \mathrm{O}$, and samples showing denitrification would tend to have high values of $\delta^{18} \mathrm{O}$ and $\delta^{15} \mathrm{~N}$ (Kendall, 1998).

Instantaneous total nitrogen loads (table 3 ) ranged from less than 1 to 62.1 pounds per day $(\mathrm{lb} / \mathrm{d})$ at the farthest downstream station on Latimer Brook (site 011277905). Total nitrogen loads at the farthest downstream stations on Oil Mill Brook (site 0112779135) and Stony Brook (site 011277916) were $11.1 \mathrm{lb} / \mathrm{d}$ and $6.9 \mathrm{lb} / \mathrm{d}$, respectively. Instantaneous total 


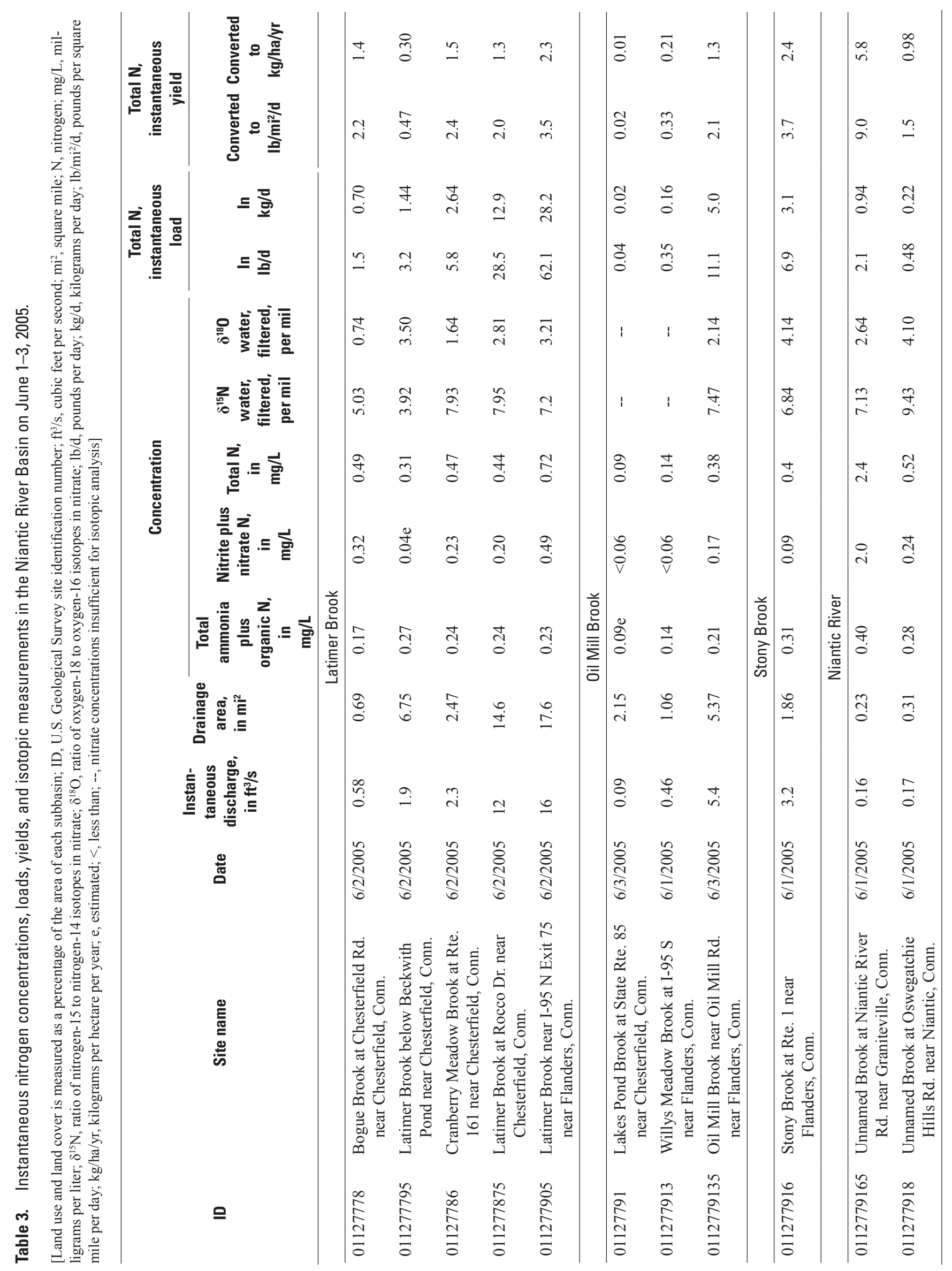




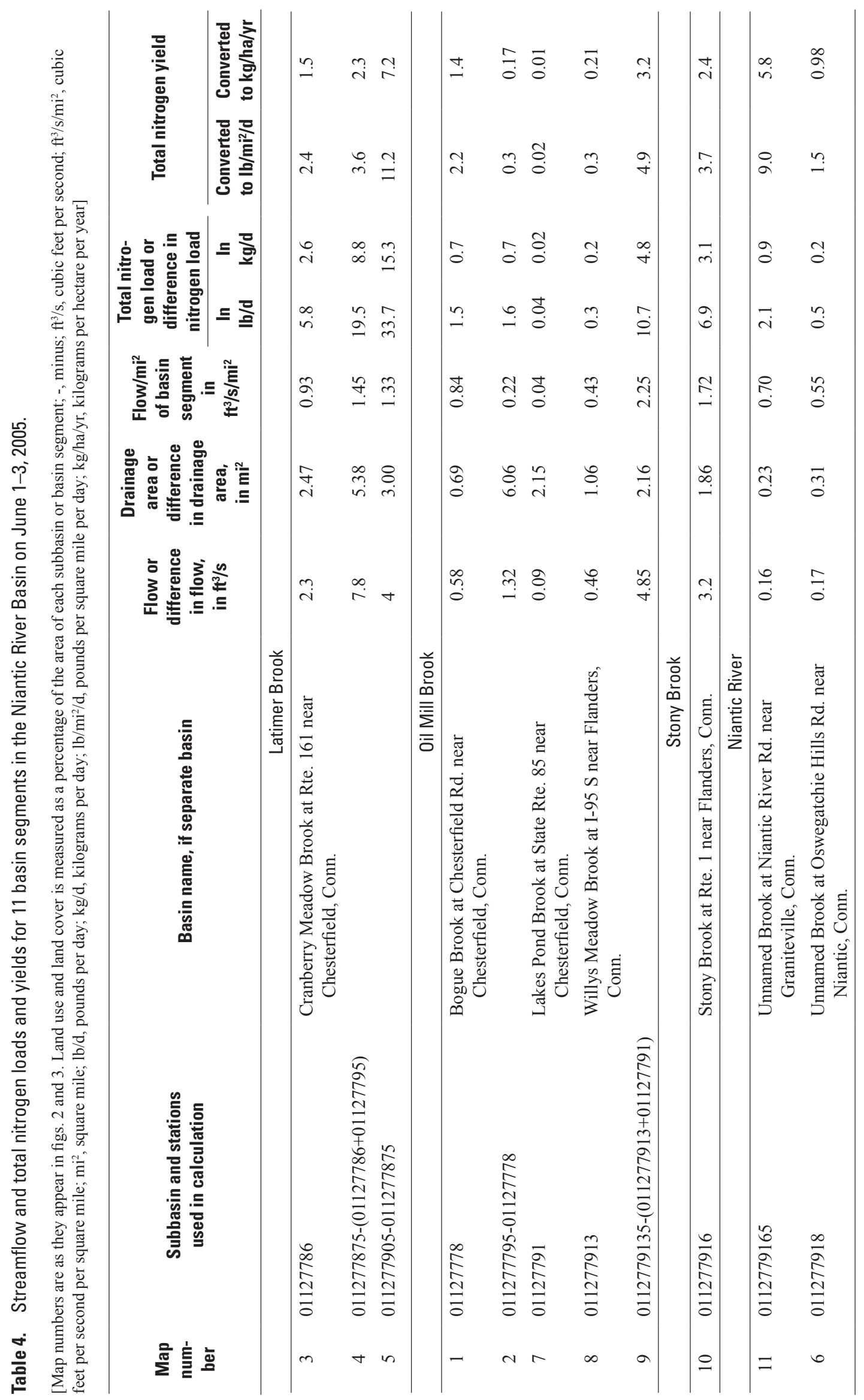




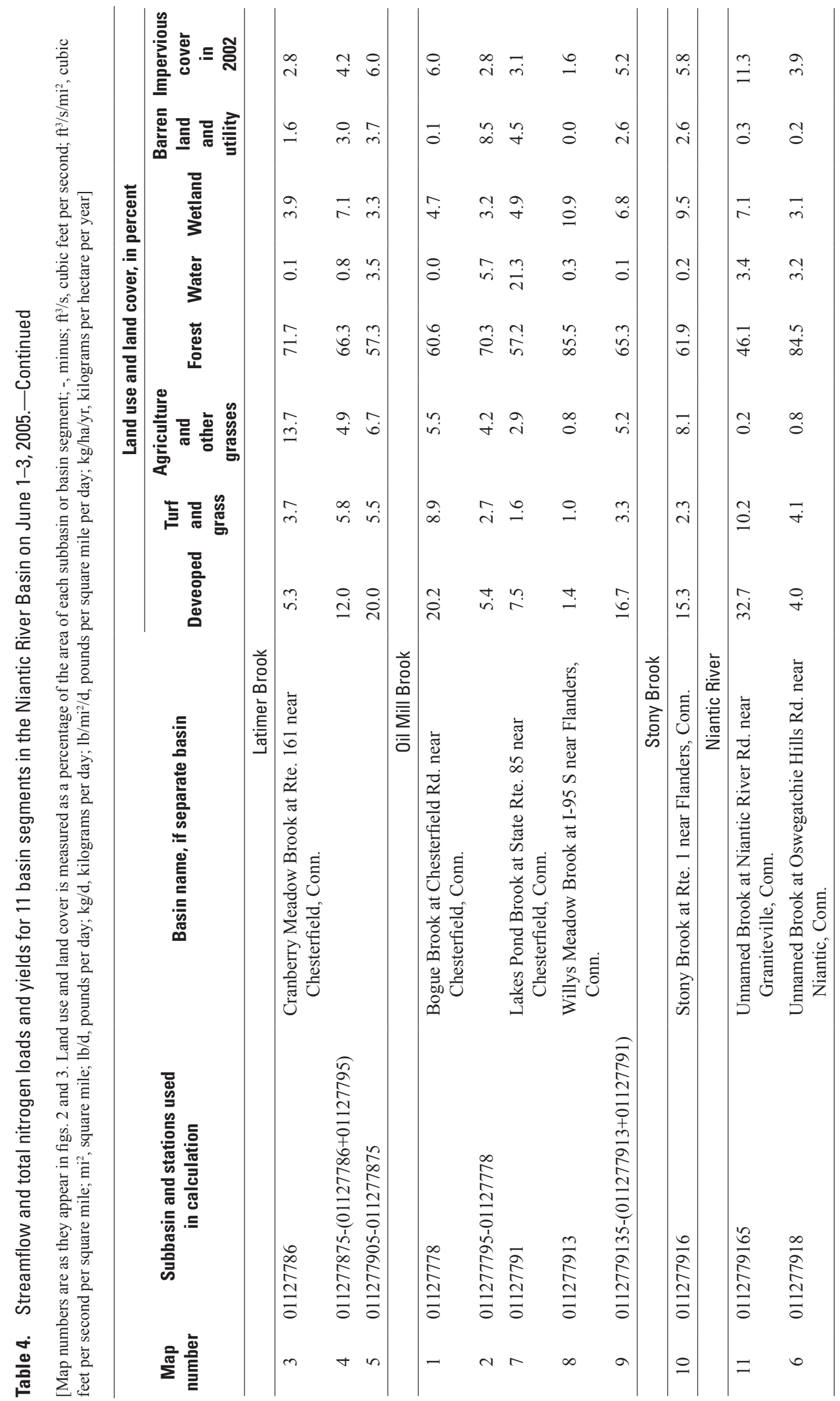




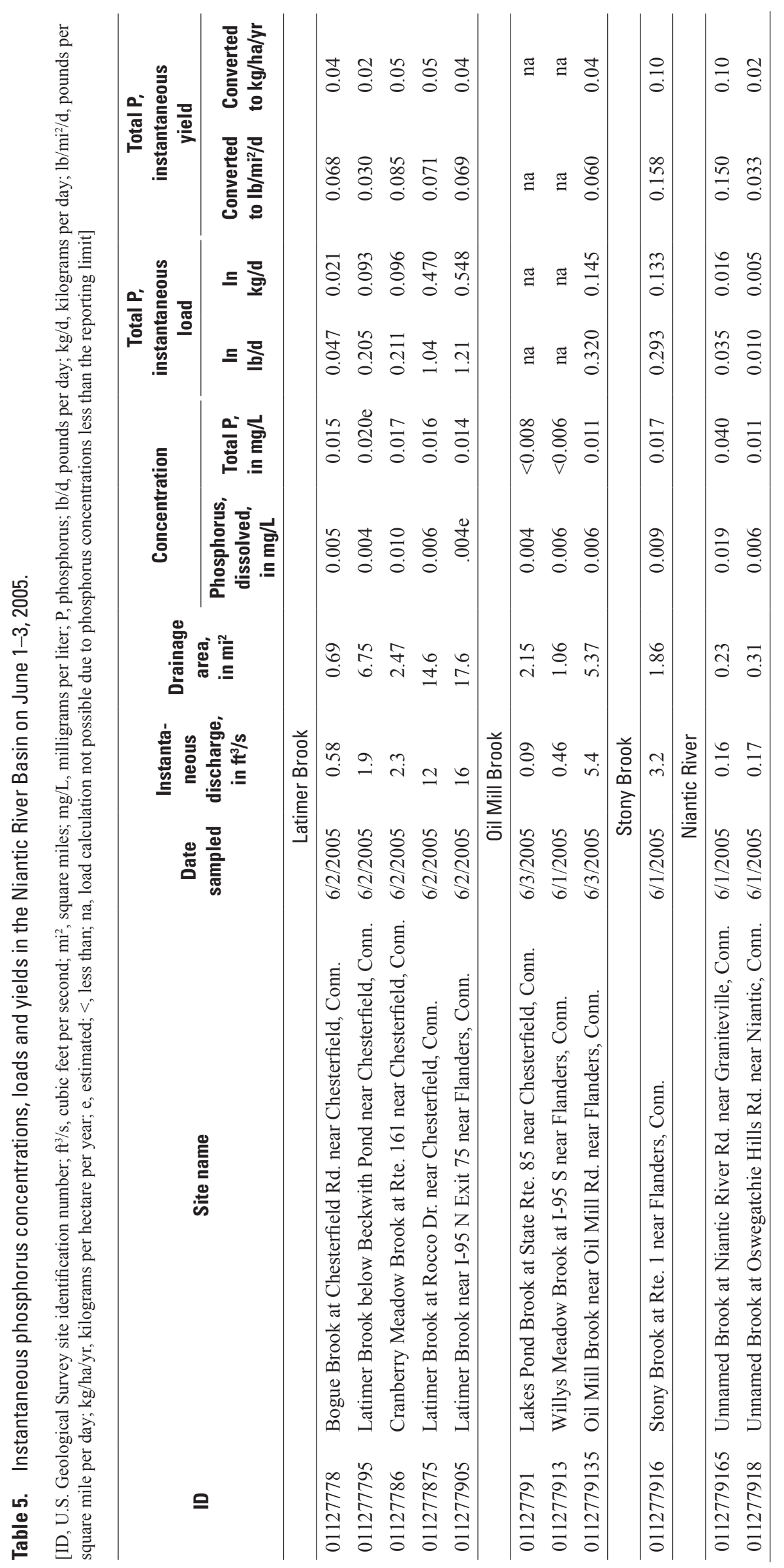




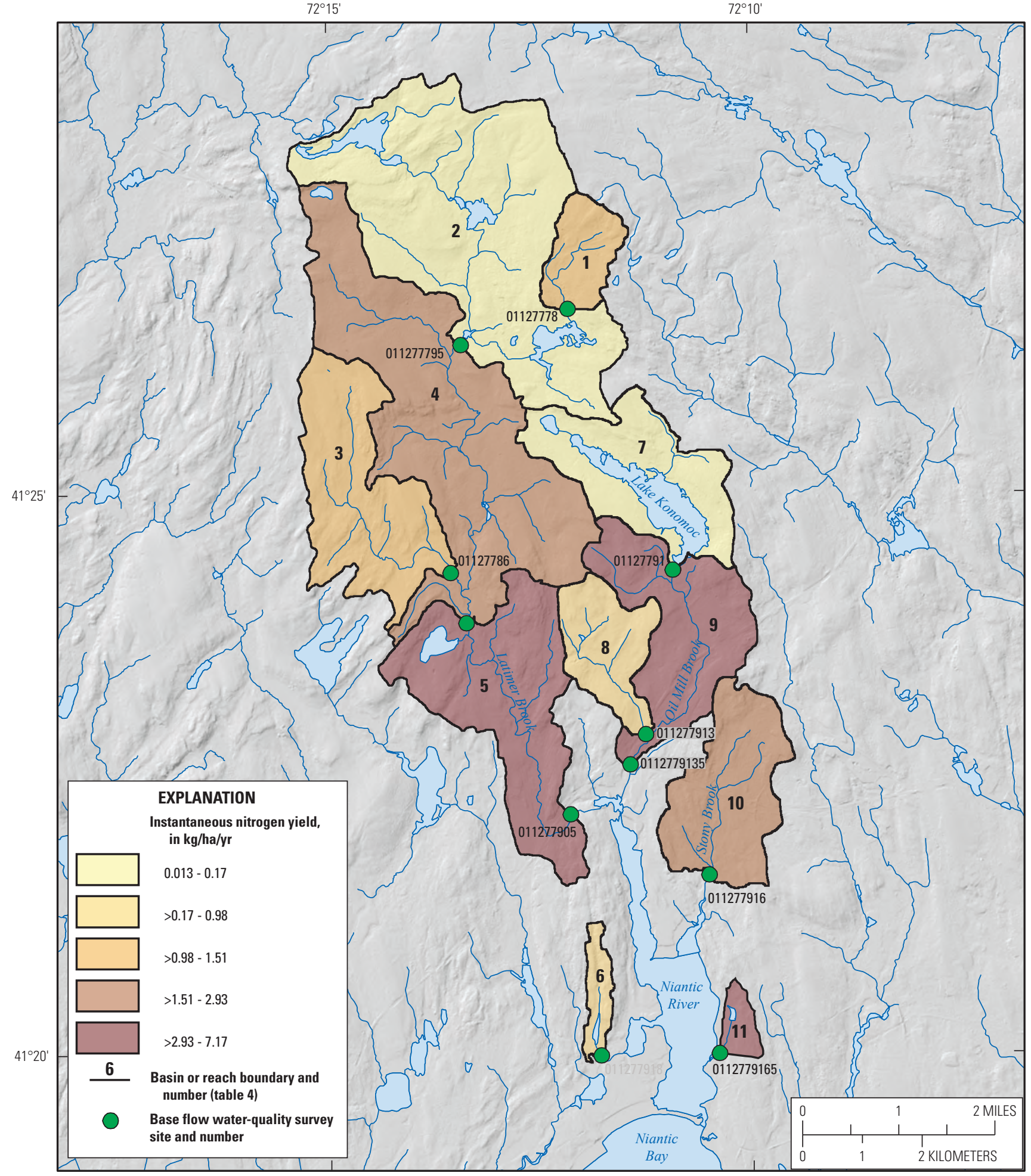

Base from University of Connecticut, Department of Agriculture and Natural Resources, 2000 NAD83 Lambert Conformal Conic projection

Figure 3. Nitrogen yields from selected basin segments in the Niantic River Basin, southeastern Connecticut, on June 1-3, 2005. kg/ha/, (kilograms per hectare per year); NAD83, North American Datum of 1983; USGS, U.S. Geological Survey. 


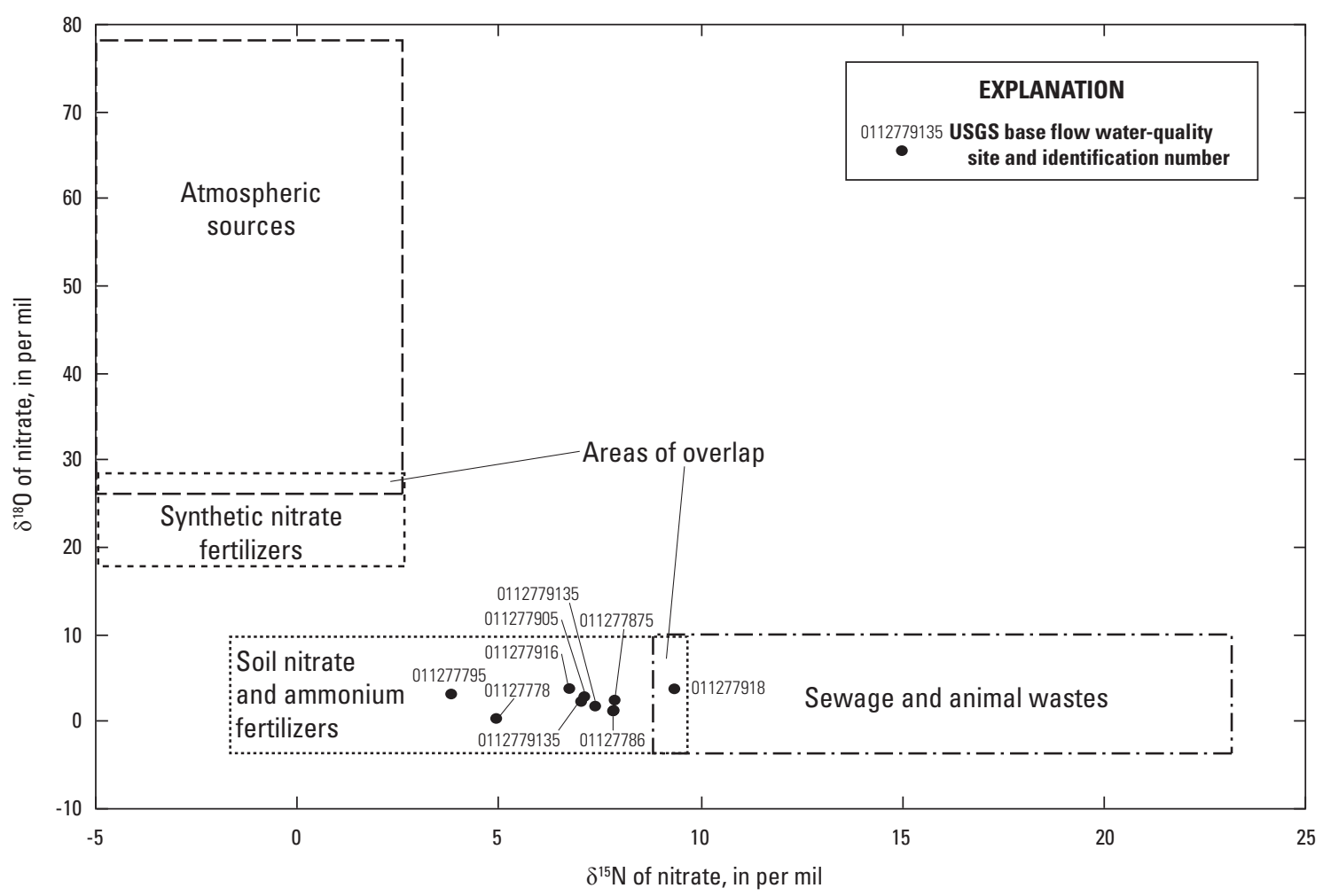

Figure 4. Approximate compositional ranges of $\delta^{15} \mathrm{~N}$ and $\delta^{18} 0$ data for sources of nitrate. Reproduced from Ging and others (1996). Water-quality samples collected June 1-3, 2005, from the Niantic River Basin, southeastern Connecticut, are plotted. $\delta^{15} \mathrm{~N}$, ratio of nitrogen-15 to nitrogen-14 isotopes of nitrate; $\delta^{18} 0$, ratio of oxygen-18 to oxygen-16 isotopes of nitrate; USGS, U.S. Geological Survey.

nitrogen yields also were calculated as gains by river reach, by subtracting the upstream loads from the loads at downstream stations and dividing by the drainage area of the reach (table 4).

Total nitrogen yields from basins or basin segments ranged from 0.02 to 11.2 pounds per square mile per day $\left(\mathrm{lb} / \mathrm{mi}^{2} / \mathrm{d} ; 0.01\right.$ to 7.2 kilograms per hectare per year ( $\mathrm{kg} / \mathrm{ha} / \mathrm{yr})$; tables 3 and 4$)$. The highest yield was measured for the segment between stations 011277905 and 011277875 on Latimer Brook (fig. 3, segment 5) and was due to an increase of $33.7 \mathrm{lb} / \mathrm{d}$ [15.3 kilograms per day $(\mathrm{kg} / \mathrm{d})]$ in total nitrogen load (table 4). The next largest yield, $9.0 \mathrm{lb} / \mathrm{mi}^{2} / \mathrm{d}$ $(5.8 \mathrm{~kg} / \mathrm{ha} / \mathrm{yr})$, was from an unnamed brook (station 0112779165; fig. 3, segment 11). Total nitrogen yields were positively correlated with the percentage of developed land use for each basin segment (fig. 5).

Sources of nitrogen in base flow are generally representative of the quality of groundwater discharging to the stream; the isotopic measurements from the water-quality samples analyzed indicate the possibility of elevated nitrogen from fertilizers and septic systems or some mixture of sources, including soil nitrate. These samples only represent base flow, and therefore, samples collected during stormwater runoff events may have different sources of nitrogen.
Instantaneous total phosphorus concentrations were generally low, ranging from less than 0.006 to $0.040 \mathrm{mg} / \mathrm{L}$. Instantaneous total phosphorus loads ranged from 0.010 to $1.21 \mathrm{lb} / \mathrm{d}$ at the farthest downstream station on Latimer Brook (site 011277905). Total phosphorus loads from the farthest downstream stations on Oil Mill Brook (site 0112779135) and Stony Brook (site 011277916 ) were $0.320 \mathrm{lb} / \mathrm{d}$ and $0.293 \mathrm{lb} / \mathrm{d}$, respectively, representing the base flow load of phosphorus to the estuary (table 5). Total phosphorus instantaneous yields ranged from 0.033 to $0.158 \mathrm{lb} / \mathrm{mi}^{2} / \mathrm{d}(0.02$ to $0.1 \mathrm{~kg} / \mathrm{ha} / \mathrm{yr})$.

\section{Tributary Monitoring From 2008 Through 2011}

\section{Streamflow}

Streamflow was greatest during water year 2010 (table 6, fig. 6) due to extreme high flows caused by excessive rainfall that occurred around March 30, 2010, when a total of 9.2 inches of rainfall was measured at USGS rain gage 4121480721223 (fig. 1) in East Lyme. Although this was an extreme event that affected the mean flows for that year, median flows were highest in water year 2009. 


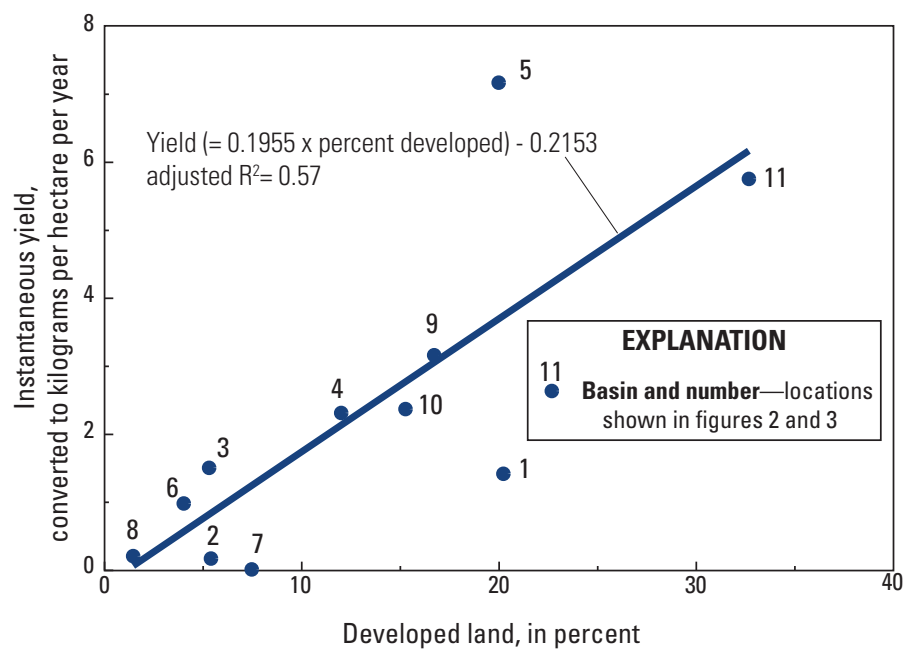

Figure 5. Instantaneous nitrogen yield by percentage of developed land for basin segments in the Niantic River Basin from water-quality samples and streamflow measurements collected June $1-3,2005$. $R^{2}$, coefficient of determination.

Table 6. Streamflow characteristics of three Niantic River tributaries in southeastern Connecticut for water years 2009-2011.

[ID, U.S. Geological Survey site identification number; $\mathrm{mi}^{2}$, square mile; $\mathrm{ft}^{3} / \mathrm{s}$, cubic feet per second; max., maximum; min., minimum]

\begin{tabular}{|c|c|c|c|c|c|c|c|c|c|}
\hline ID & Site name & $\begin{array}{c}\text { Drainage } \\
\text { area, } \\
{\text { in } \mathrm{mi}^{2}}^{2}\end{array}$ & $\begin{array}{l}\text { Minimum, } \\
\text { in } \mathrm{ft}^{3} / \mathrm{s}\end{array}$ & $\begin{array}{c}\text { Lower } \\
\text { quartile, } \\
\text { in } \mathrm{ft}^{3} / \mathrm{s}\end{array}$ & $\begin{array}{l}\text { Median, } \\
\text { in } \mathrm{ft}^{3} / \mathrm{s}\end{array}$ & $\begin{array}{l}\text { Mean, } \\
\text { in } \mathrm{ft}^{3} / \mathrm{s}\end{array}$ & $\begin{array}{c}\text { Upper } \\
\text { quartile, } \\
\text { in } \mathrm{ft}^{3} / \mathrm{s}\end{array}$ & $\begin{array}{l}\text { Maximum, } \\
\text { in } \mathrm{ft}^{3} / \mathrm{s}\end{array}$ & $\begin{array}{c}\text { Runoff, } \\
\text { in } \\
\text { inches }\end{array}$ \\
\hline \multicolumn{10}{|c|}{ Water year 2009} \\
\hline 011277905 & $\begin{array}{l}\text { Latimer Brook near I-95 N Exit } 75 \text { near } \\
\text { Flanders, Conn. }\end{array}$ & 17.6 & 2.8 & 16.0 & 29.0 & 36.0 & 41.0 & 462 & 27.8 \\
\hline 011277914 & $\begin{array}{l}\text { Oil Mill Brook at Gurley Rd. near East } \\
\text { Lyme, Conn. }\end{array}$ & 5.67 & 1.6 & 4.5 & 7.0 & 8.5 & 10.0 & 92 & 20.4 \\
\hline 011277916 & Stony Brook at Rte. 1 near Flanders, Conn. & 1.86 & 0.48 & 2.0 & 3.8 & 4.5 & 5.3 & 56 & 33.0 \\
\hline \multicolumn{10}{|c|}{ Water year 2010} \\
\hline 011277905 & $\begin{array}{l}\text { Latimer Brook near I-95 N Exit } 75 \text { near } \\
\text { Flanders, Conn. }\end{array}$ & 17.6 & 1.2 & 8.9 & 20.0 & 43.3 & 42.0 & 1,350 & 33.4 \\
\hline 011277914 & $\begin{array}{l}\text { Oil Mill Brook at Gurley Rd. near East } \\
\text { Lyme, Conn. }\end{array}$ & 5.67 & 0.98 & 2.9 & 5.9 & 9.7 & 10.0 & 330 & 23.2 \\
\hline 011277905 & $\begin{array}{l}\text { Latimer Brook near I-95 N Exit } 75 \text { near } \\
\text { Flanders, Conn. }\end{array}$ & 17.6 & 2.1 & 9.2 & 16.0 & 28.3 & 32.0 & 266 & 21.8 \\
\hline 011277914 & $\begin{array}{l}\text { Oil Mill Brook at Gurley Rd. near East } \\
\text { Lyme, Conn. }\end{array}$ & 5.67 & 1.5 & 3.1 & 7.0 & 8.0 & 10.0 & 54 & 19.2 \\
\hline 011277916 & Stony Brook at Rte. 1 near Flanders, Conn. & 1.86 & 0.5 & 1.4 & 2.3 & 3.7 & 4.3 & 30 & 27.3 \\
\hline
\end{tabular}




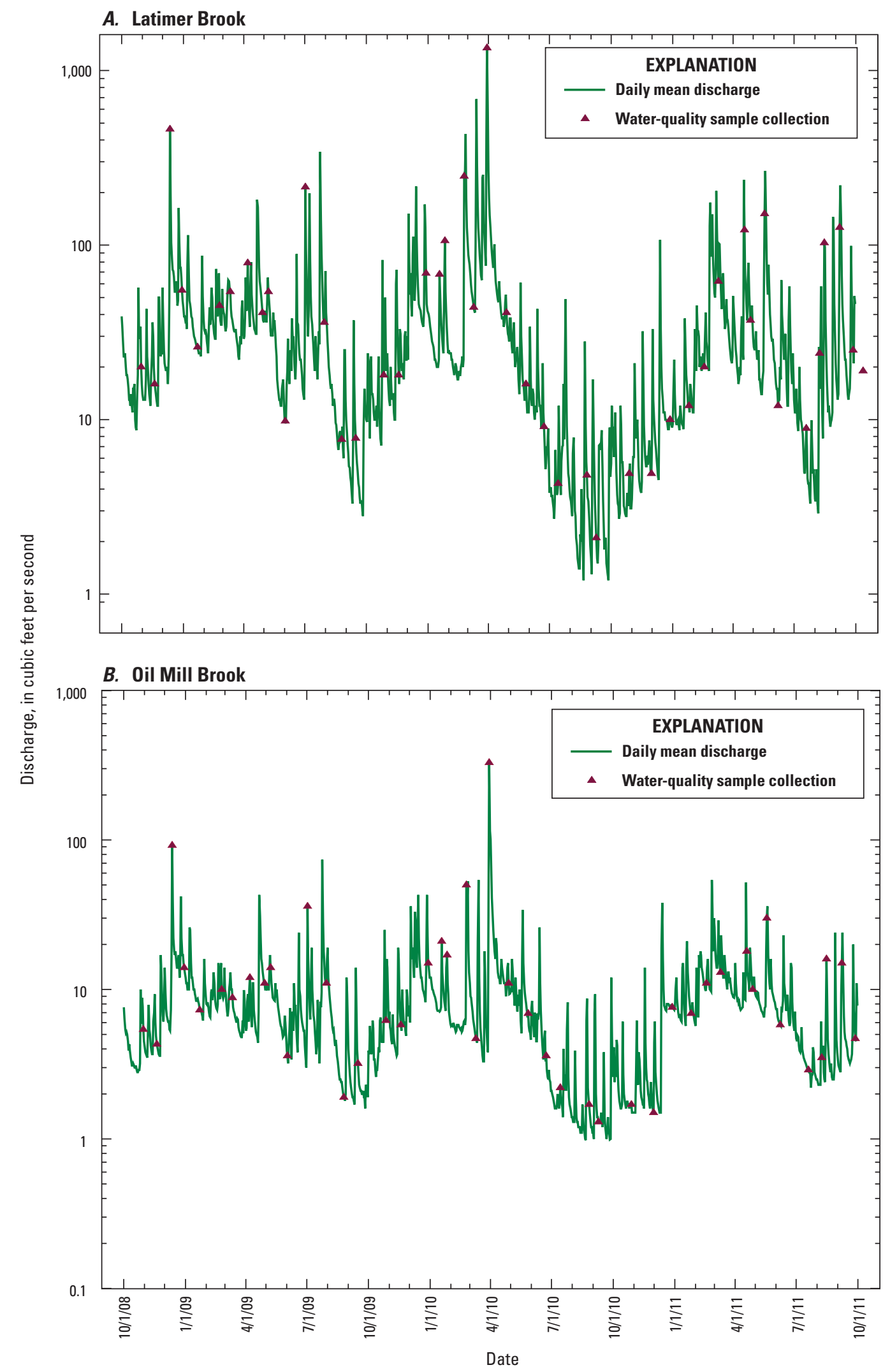

Figure 6. Daily discharge from $A$, Latimer Brook; $B$, Oil Mill Brook; $C$, Stony Brook tributaries of the Niantic River, showing dates of samples collected, Niantic River Basin, southeastern Connecticut. 


\section{Stony Brook}

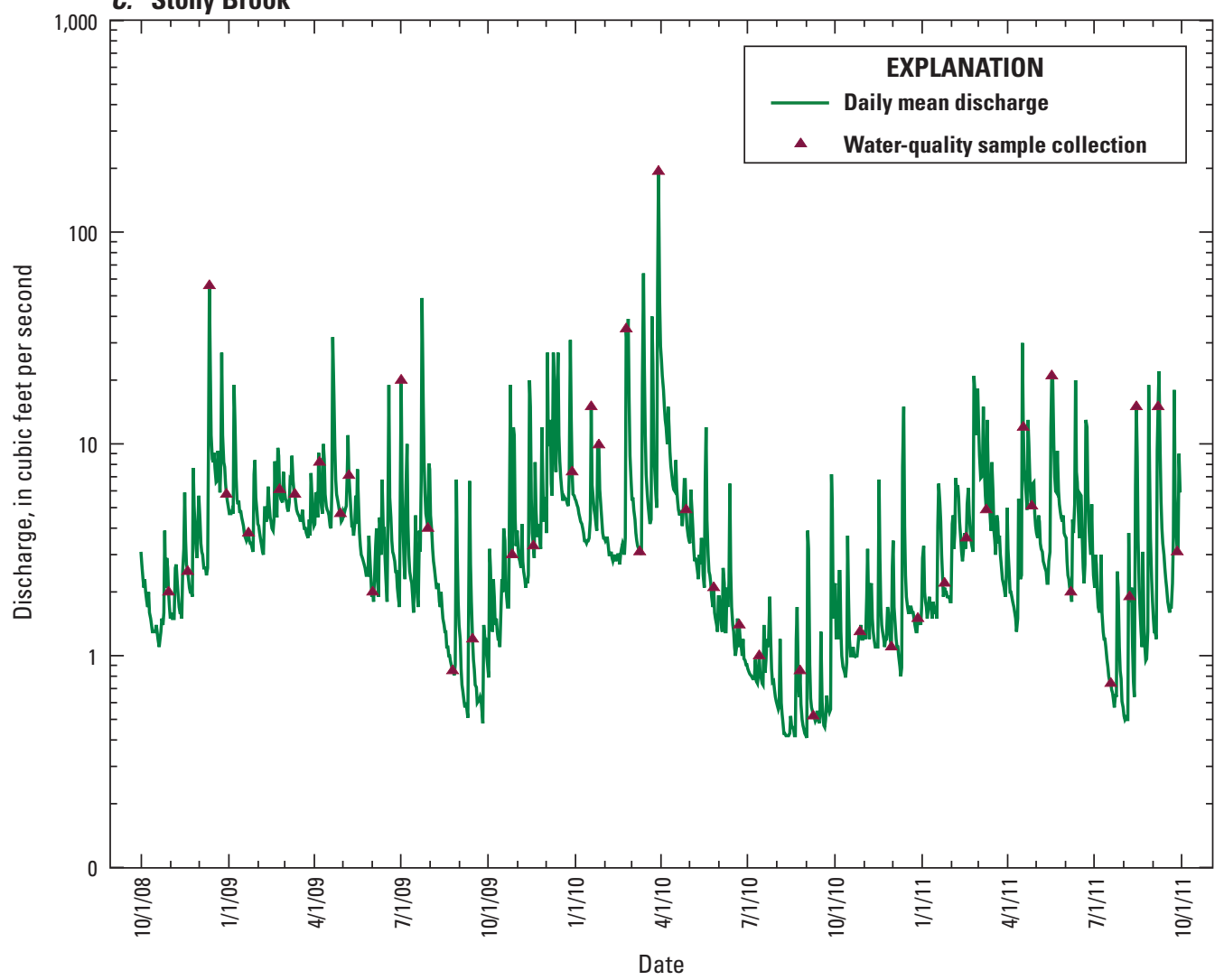

Figure 6. Daily discharge from $A$, Latimer Brook; $B$, Oil Mill Brook; $C$, Stony Brook tributaries of the Niantic River, showing dates of samples collected, Niantic River Basin, southeastern Connecticut.-Continued

The total mean daily flow from the three major tributaries with continuous streamflow ranged from $40 \mathrm{ft}^{3} / \mathrm{s}$ (25.9 million gallons per day $(\mathrm{Mgal} / \mathrm{d}))$ in water year 2011 to $58.6 \mathrm{ft}^{3} / \mathrm{s}(37.8 \mathrm{Mgal} / \mathrm{d})$ in water year 2010 .

The annual total runoff (the part of precipitation appearing in surface streams) from each of the watersheds was variable. Stony Brook had the greatest amount of runoff ranging from 27.3 inches in water year 2011 to 40.7 inches in water year 2010. The other two sites had lower runoff for each of the three water years likely due to water diversions from reservoirs in the Latimer Brook and Oil Mill Brook Basins. If runoff from Stony Brook (which has no reservoirs) is representative of the amount of natural runoff for the region, then the difference between the runoff from Oil Mill Brook and Latimer Brook relative to Stony Brook should be generally representative of the amount of water diverted out of the Niantic Basin (assuming change in storage in the reservoirs is negligible). The total difference in runoff between Stony Brook and the other two tributaries (Oil Mill Brook and Latimer Brook) ranged from 10.5 to $16.9 \mathrm{ft}^{3} / \mathrm{s}$ (7.8 to $10.9 \mathrm{Mgal} / \mathrm{d}$ ), indicating that flows to the Niantic River have been altered substantially by diversion. The estimated demand for water from users in the city of New London for 2010 was expected to be $5.9 \mathrm{Mgal} / \mathrm{d}$, based on projections in the regional water supply plan (Southeastern Connecticut Water Authority, 2003). Differences between the estimated diversions and the calculated differences among tributaries described above may be attributed to (1) the assumption that runoff from Stony Brook is representative of prediversion runoff from the other stations; (2) changes in surface water storage; (3) small errors in measurement of watershed area or streamflow; or (4) diversions of water that were larger than those projected in the water supply plan of 2003.

The diversion of water from the Niantic River likely affects the nutrient cycling of the downstream estuary by (1) reducing the overall loading rate of nutrients that originate upstream of the water diversion and (2) increasing the freshwater residence time of the estuary. Nutrient loads are reduced, but the freshwater that remains in the estuary is likely to reside in the estuary for a longer time period. The remaining nutrients have not been diluted by the lower concentrations of nutrients that would have originated in the forested watersheds upstream of water supply diversions. 


\section{Nitrogen}

Concentrations of total nitrogen (fig. 7; table 7) were generally low at all three stations relative to many locations in Connecticut. The highest concentrations of total nitrogen were in samples from the Latimer Brook site, whereas Oil Mill Brook and Stony Brook had similar distributions of concentration for samples collected from 2008 through 2012 (fig. 7). Latimer Brook had higher concentrations of total nitrogen than did Oil Mill Brook and Stony Brook, which had similar distributions of concentration for samples collected from 2008 through 2012 (fig.7; table7). The median concentrations of total nitrogen at these three sites were lower than the median value of $0.67 \mathrm{mg} / \mathrm{L}$ of data from 38 stations on streams draining to Long Island Sound.

The mean value of total nitrogen was $0.42 \mathrm{mg} / \mathrm{L}$ for Oil Mill Brook and Stony Brook and $0.62 \mathrm{mg} / \mathrm{L}$ for Latimer Brook. These mean total nitrogen concentrations are below the $0.71 \mathrm{mg} / \mathrm{L}$ USEPA ecoregion XIV (Eastern Coastal Plain) total nitrogen recommended criterion for streams (U.S. Environmental Protection Agency, 2000).

Concentrations of total ammonia plus organic nitrogen ranged from less 0.07 to $0.93 \mathrm{mg} / \mathrm{L}$ (fig. 8; table 7). Ammonia plus organic nitrogen typically represented less than 50 percent of the total nitrogen concentrations at the Latimer Brook site, but represented more than 50 percent of the total nitrogen concentrations in samples from the Oil Mill Brook and Stony Brook sites. Concentrations of dissolved ammonia typically represented less than 10 percent of the total ammonia plus organic nitrogen, indicating that organic nitrogen is dominant species.

Total nitrogen loads for all three Niantic River tributaries combined for water years 2009 through 2011 ranged from 41,400 to $60,700 \mathrm{lb}$ (table 8 ). Total nitrogen loads were consistent with drainage area with the largest loads from Latimer Brook, followed by Oil Mill Brook and Stony Brook. The largest loads were estimated for water year 2010, likely caused at least in part by the additional runoff associated with the storm of March 30, 2010.

Loads of total ammonia plus organic nitrogen (table 8) for all three Niantic River tributaries combined ranged from $22,000 \mathrm{lb}$ in water year 2011 to $35,600 \mathrm{lb}$ in water year 2010. Total ammonia plus organic nitrogen represented 52 to 59 percent of the load of total nitrogen from the three Niantic River tributaries. Loads of total ammonia plus organic nitrogen were largest relative to loads of total nitrogen at Oil Mill Brook and Stony Brook, representing more than 60 percent of the load of total nitrogen and as much as 80 percent of the load for Stony Brook in 2010.

Total nitrogen yields (table 8) were generally highest at Latimer Brook, followed by Stony Brook and Oil Mill Brook. The total nitrogen yields at all three tributaries are generally

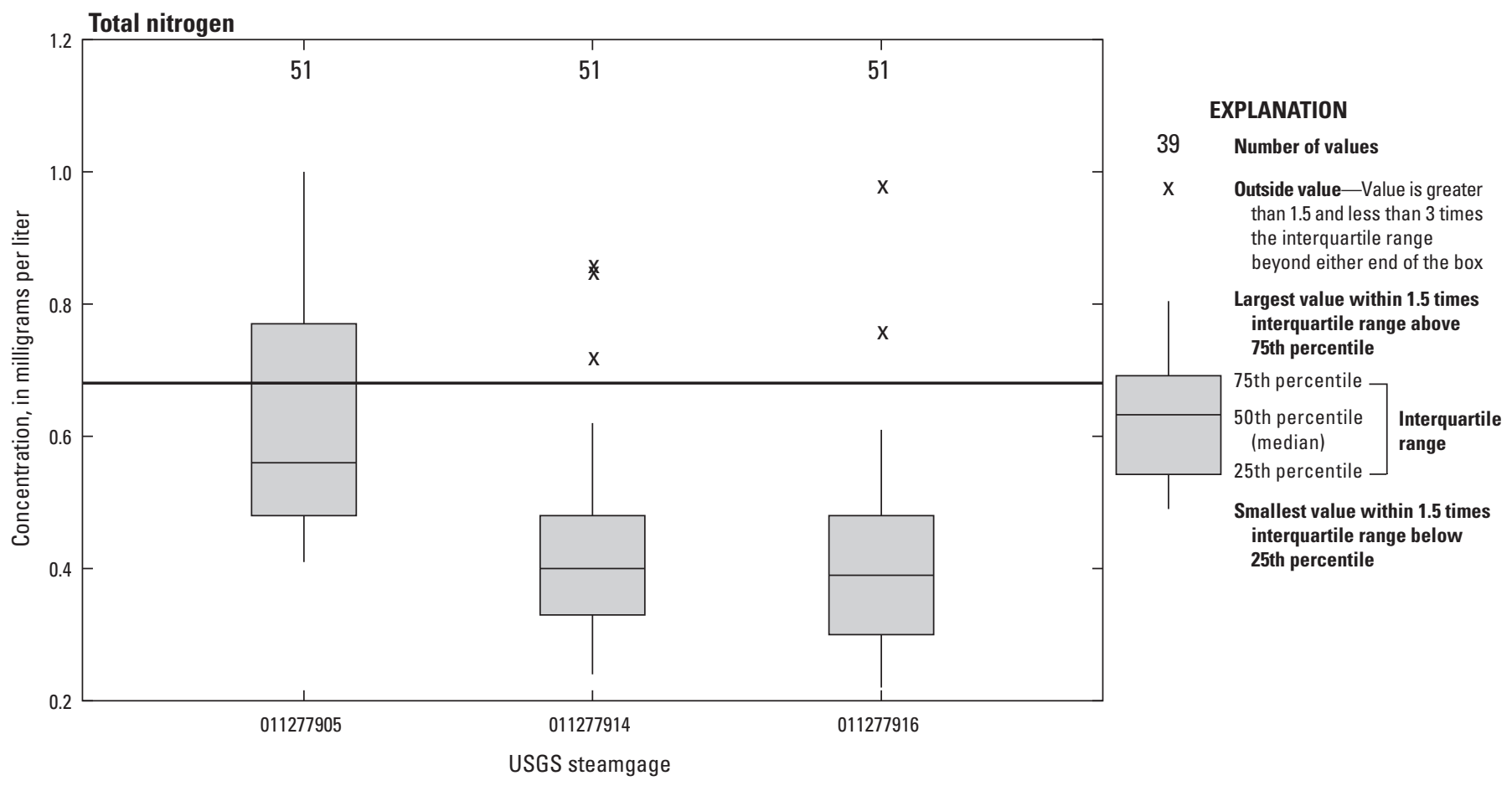

Figure 7. Distribution of total nitrogen concentrations in the Niantic River Basin in southeastern Connecticut from August 2008 through February 2012. Data shown are from U.S. Geological Survey (USGS) streamgages 011277905 at Latimer Brook, 011277914 at Oil Mill Brook, and 011277916 at Stony Brook. Line represents the median of samples from 38 stations in the Long Island Sound watershed from October 1995-September 2009. 


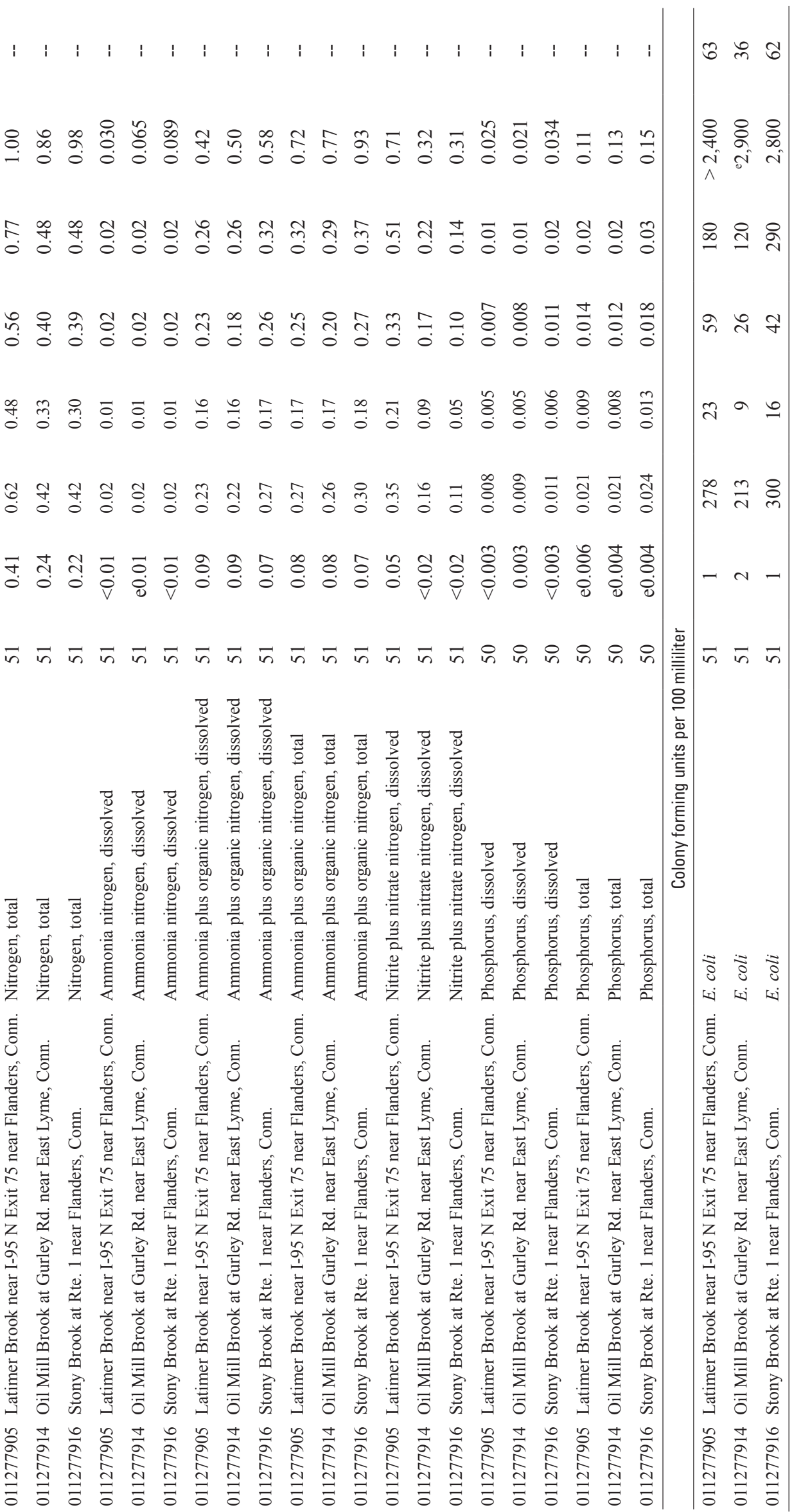




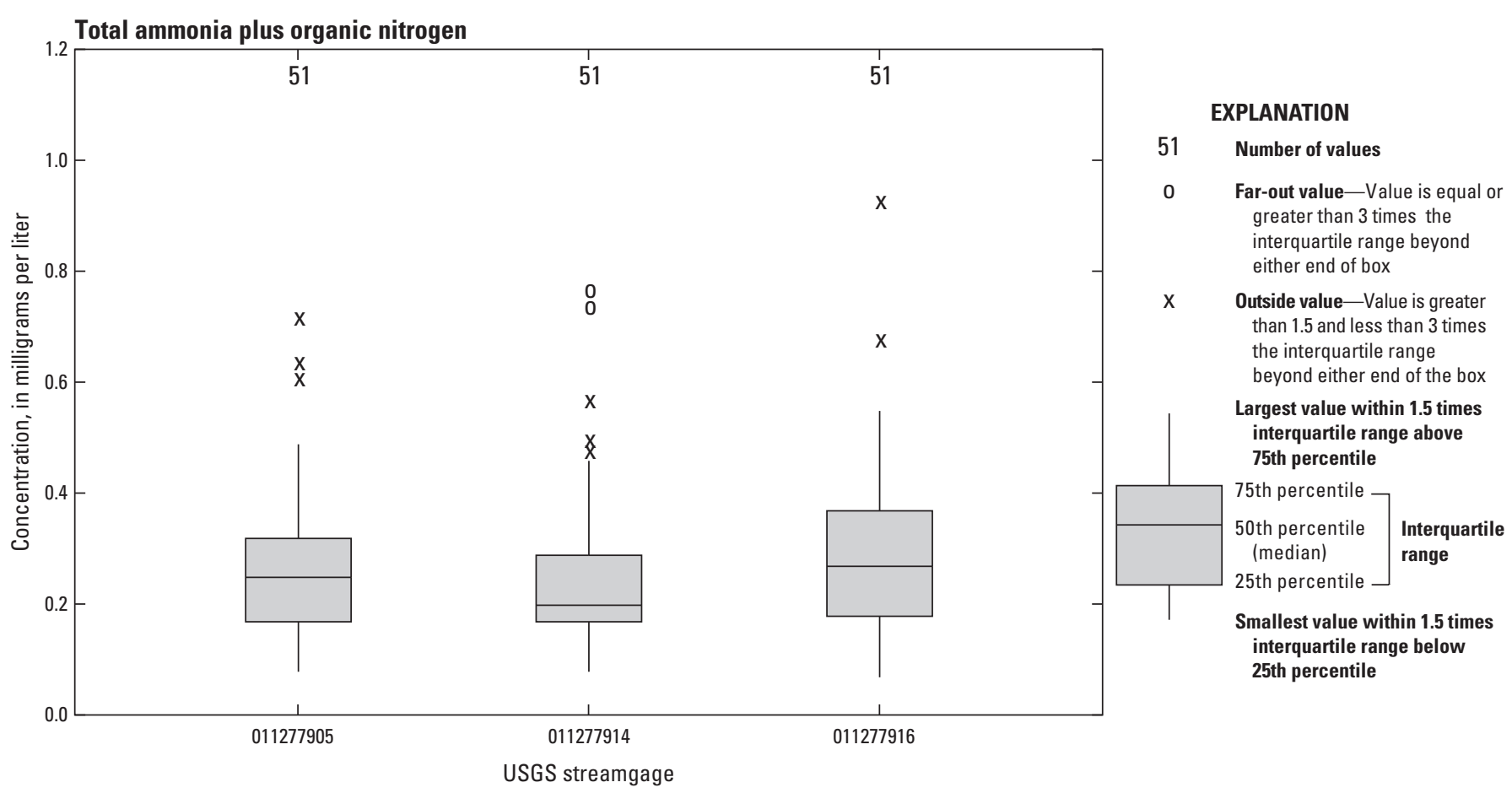

Figure 8. Distribution of total ammonia plus organic nitrogen concentrations in the Niantic River Basin in southeastern Connecticut from August 2008 through February 2012. Data shown are from U.S. Geological Survey (USGS) streamgages 011277905 at Latimer Brook, 011277914 at Oil Mill Brook, and 011277916 at Stony Brook.

representative of loads from forested basins, although total nitrogen yields from Latimer Brook are slightly higher than the maximum 2,000 lb/ $\mathrm{mi}^{2} / \mathrm{yr}$ for forested basins reported by Trench (2000). Yields of total nitrogen may be lowest at Oil Mill Brook because of the lowest amount of developed and agricultural land of the three basins (table 1). Nitrogen loads and yields at Oil Mill Brook and Latimer Brook are likely less than they would be under natural flow conditions because of the large diversions of water upstream from the streamgages. Stony Brook had the highest yield of total ammonia plus organic nitrogen.

\section{Phosphorus}

Total phosphorus concentrations in most samples were low in all three tributaries of the Niantic River, ranging from less than 0.004 to $0.15 \mathrm{mg} / \mathrm{L}$; dissolved phosphorus concentrations ranged from less than $0.003 \mathrm{mg} / \mathrm{L}$ to $0.034 \mathrm{mg} / \mathrm{L}$ (fig. 9, table 7). Most samples were below the 0.031-mg/L USEPA total phosphorus criterion for streams for ecoregion XIV (U.S. Environmental Protection Agency, 2000). Dissolved phosphorus typically was less than 50 percent of the total phosphorus in samples from Latimer Brook and Oil Mill Brook, but represented more than 50 percent of total phosphorus in Stony Brook. Selected statistics on phosphorus concentrations are in table 7.
The total phosphorus loads (table 9) from all three Niantic River tributaries ranged from $1,770 \mathrm{lb}$ in water year 2011 to 3,540 lb in water year 2010. Latimer Brook accounted for 72 to 75 percent of the total phosphorus load from the three tributaries; Oil Mill Brook and Stony Brook, 16 to 16.6 percent and 9.7 to 11 percent, respectively.

Total phosphorus yields were highest at Stony Brook, followed by Latimer Brook and Oil Mill Brook. Yields ranged from a low of $52 \mathrm{lb} / \mathrm{mi}^{2} / \mathrm{yr}$ at Oil Mill Brook in water year 2011 to $185 \mathrm{lb} / \mathrm{mi}^{2} / \mathrm{yr}$ at Stony Brook in water year 2010. Yields of total phosphorus from Latimer Brook and Oil Mill Brook are likely also lower than would be expected without water diversions from the upper watershed.

\section{Escherichia coli}

The geometric mean values of $E$. coli densities at the three sampling stations from August 2008 through February 2012 (table 7) meet the Connecticut water-quality standard of less than 126 colony-forming units (cfu) per 100 milliliters $(\mathrm{mL})$ for all forms of water recreation (Connecticut Department of Energy and Environmental Protection, 2011b). All three monitoring stations had single sample maximum densities in excess of the $235 \mathrm{cfu}$ per $100 \mathrm{~mL}, 410 \mathrm{cfu}$ per $100 \mathrm{~mL}$, and $576 \mathrm{cfu}$ per $100 \mathrm{~mL}$ standards for designated swimming, nondesignated swimming, and other water 
Table 8. Loads and yields of total nitrogen and total ammonia plus organic nitrogen for three stations in the Niantic River Basin in southeastern Connecticut from October 2008 through September 2011.

[ID, U.S. Geological Survey site identification number; $1 \mathrm{~b} / \mathrm{d}$, pounds per day; $1 \mathrm{~b} / \mathrm{yr}$, pounds per year; $1 \mathrm{~b}$, pounds; $1 \mathrm{~b} / \mathrm{mi}^{2} / \mathrm{yr}$, pounds per square mile per year; $\mathrm{kg} / \mathrm{ha} / \mathrm{yr}$, kilograms per hectare per year]

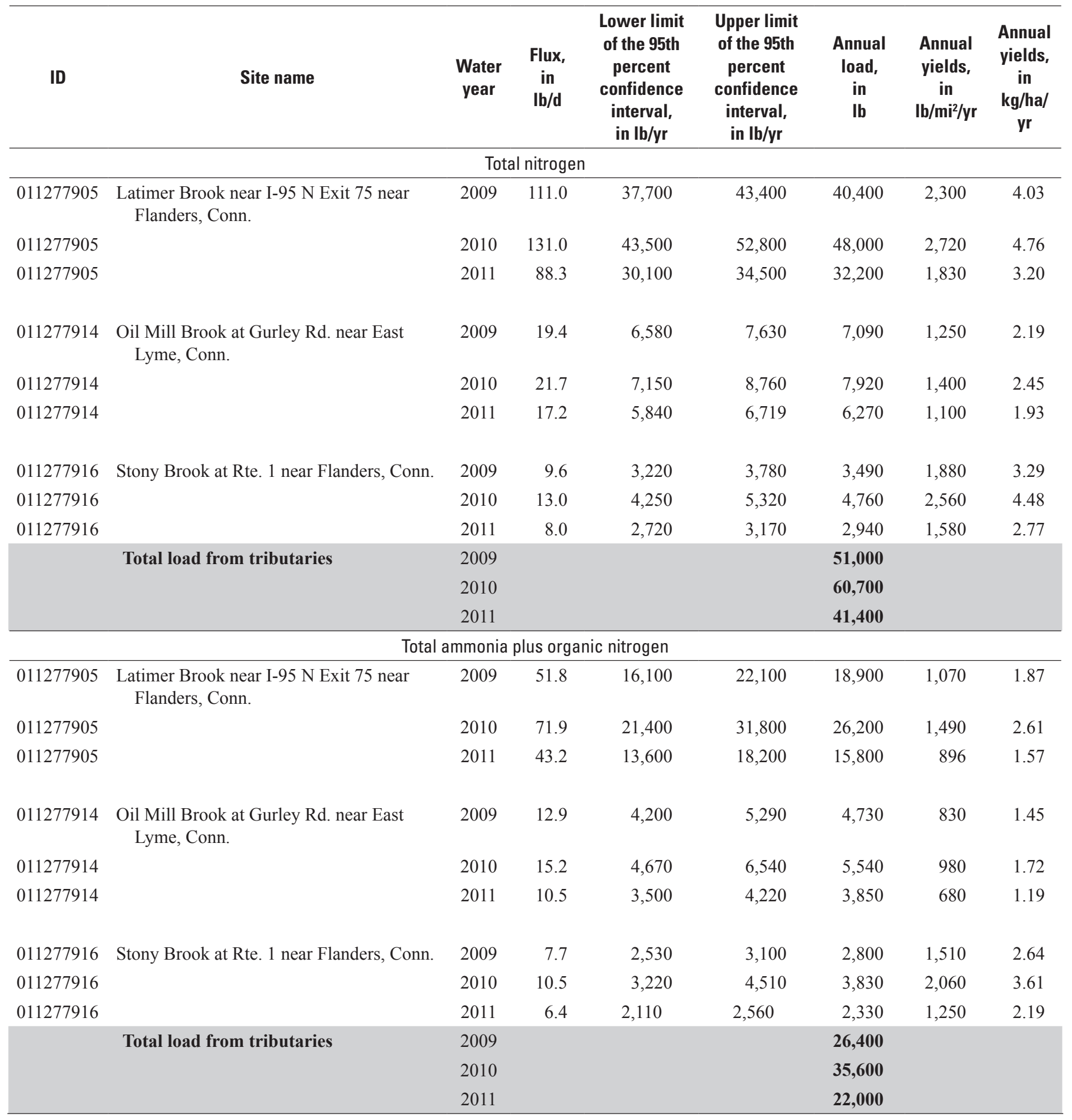




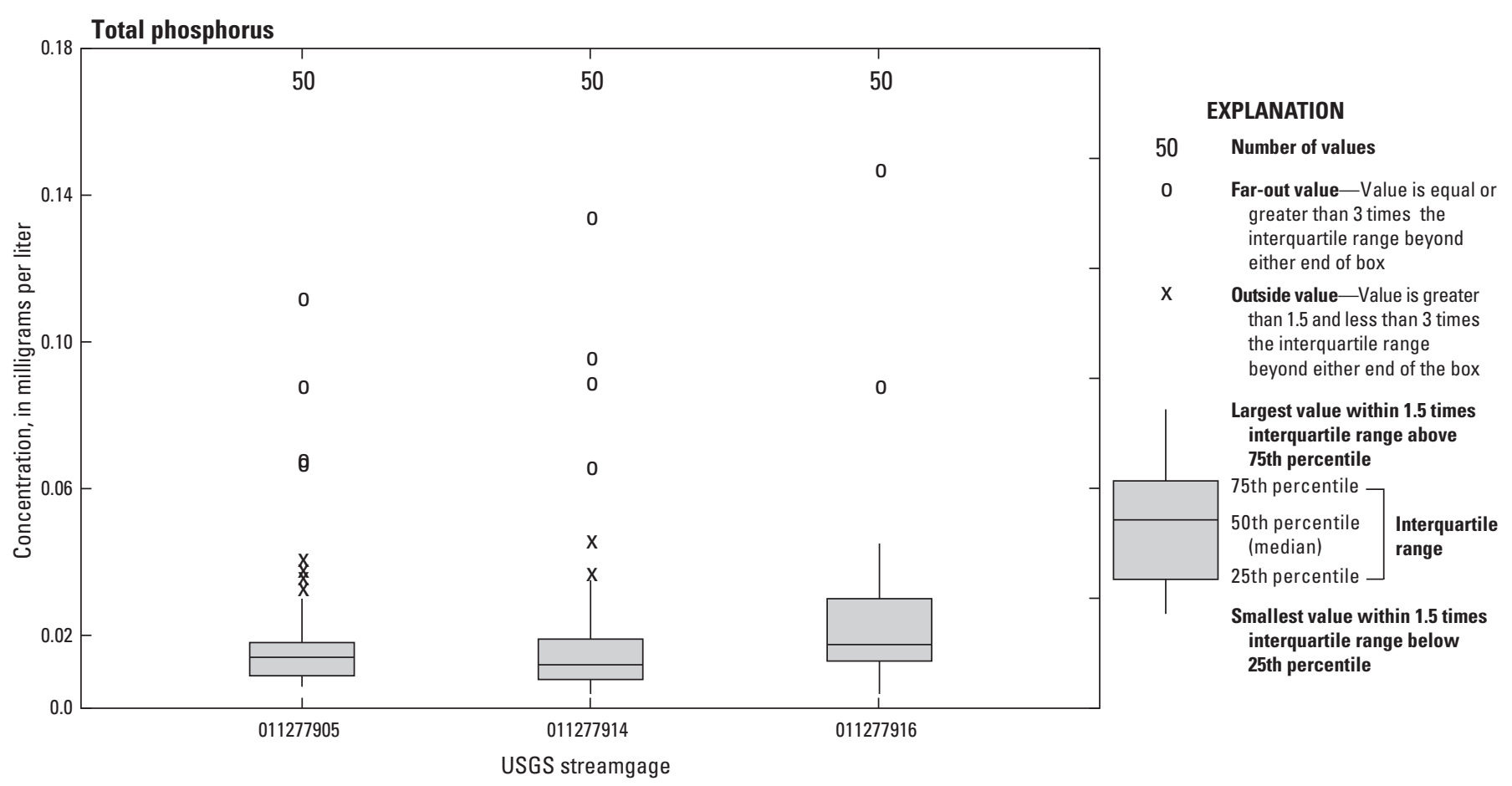

Figure 9. Distribution of total phosphorus concentrations in the Niantic River Basin in southeastern Connecticut from August 2008 through February 2012. Data shown are from U.S. Geological Survey (USGS) streamgages 011277905 at Latimer Brook, 011277914 at Oil Mill Brook, and 011277916 at Stony Brook.

recreation, respectively (table 7). A Kruskal-Wallis multiple comparison test determined that the distributions of $E$. coli densities were not significantly different among water-quality samples from the three tributaries (fig. 10).

Wet weather samples (stormflow) were separated from base flow samples for each station by using the base flow separation program PART (Rutledge, 1998) to classify samples as base flow versus storm runoff. Samples collected on days when at least 80 percent of the flow was base flow were considered to be dry weather samples, and samples from days when more than 20 percent of the flow was from stormwater runoff were classified as wet weather samples. Samples of each type (dry and wet) were plotted on cumulative probability plots for comparison of the E. coli distributions (fig. 11A-C). Wet weather samples at all three sites had a higher probability of exceeding Connecticut water-quality standards. The source of these elevated $E$. coli densities is likely stormwater runoff.

\section{Summary and Conclusions}

A study of the concentrations and loads of nitrogen and phosphorus and the densities of Escherichia coli (E. coli) bacteria in the Niantic River Basin was conducted by the U.S. Geological Survey (USGS) in cooperation with the Connecticut Department of Energy and Environmental Protection in June 2005 and from 2008 through 2011. High nitrogen loads from the Niantic River Basin have the potential to adversely affect eelgrass growth and survival in the Niantic River. Eelgrass is an important habitat for finfish and shellfish. In addition, several downstream reaches of streams in the Niantic River Basin are impaired because of $E$. coli densities that exceed State of Connecticut water-quality standards.

Land use in the Niantic River Basin is dominated by forested land; about 21 percent of the land in the watershed has been developed for residential, commercial, or agricultural uses. The surficial geology of the basin is dominated by glacial till deposits. Glacial stratified deposits are present in about 17 percent of the watershed and are an important source of base flow to Niantic River tributaries and the Niantic River.

Water-quality sampling was conducted in subbasins of the watershed at 11 locations in June 2005 as part of a base flow water-quality survey to determine the distribution of nutrient loads from groundwater to Niantic River tributaries. Samples were analyzed for nitrogen and phosphorus constituents and nitrogen and oxygen isotopes of nitrate in order to identify potential sources of nitrogen.

Concentrations of total nitrogen during this base flow survey ranged from 0.09 to 2.4 milligrams per liter (mg/L). Values of $\delta^{15} \mathrm{~N}$ and $\delta^{18} \mathrm{O}$ in nitrate ranged from 3.92 to 9.43 per mil and 0.74 to 4.10 per mil, respectively. The combinations indicated that the sources of nitrate in most samples are fertilizer or soil nitrate, sewage or animal waste, or a mixture of two or more sources. Instantaneous loads of total nitrogen ranged from 0.04 to 62.1 pounds per day $(\mathrm{lb} / \mathrm{d})$, 
Table 9. Loads and yields of total and dissolved phosphorus for three U.S. Geological Survey streamgages in the Niantic River Basin in southeastern Connecticut from October 2008 through September 2011.

[ID, U.S. Geological Survey site identification number; lb/d, pounds per day; lb/yr, pounds per year; lb, pounds; $1 \mathrm{~b} / \mathrm{mi}^{2} / \mathrm{yr}$, pounds per square mile per year; $\mathrm{kg} / \mathrm{ha} / \mathrm{yr}$, kilograms per hectare per year]

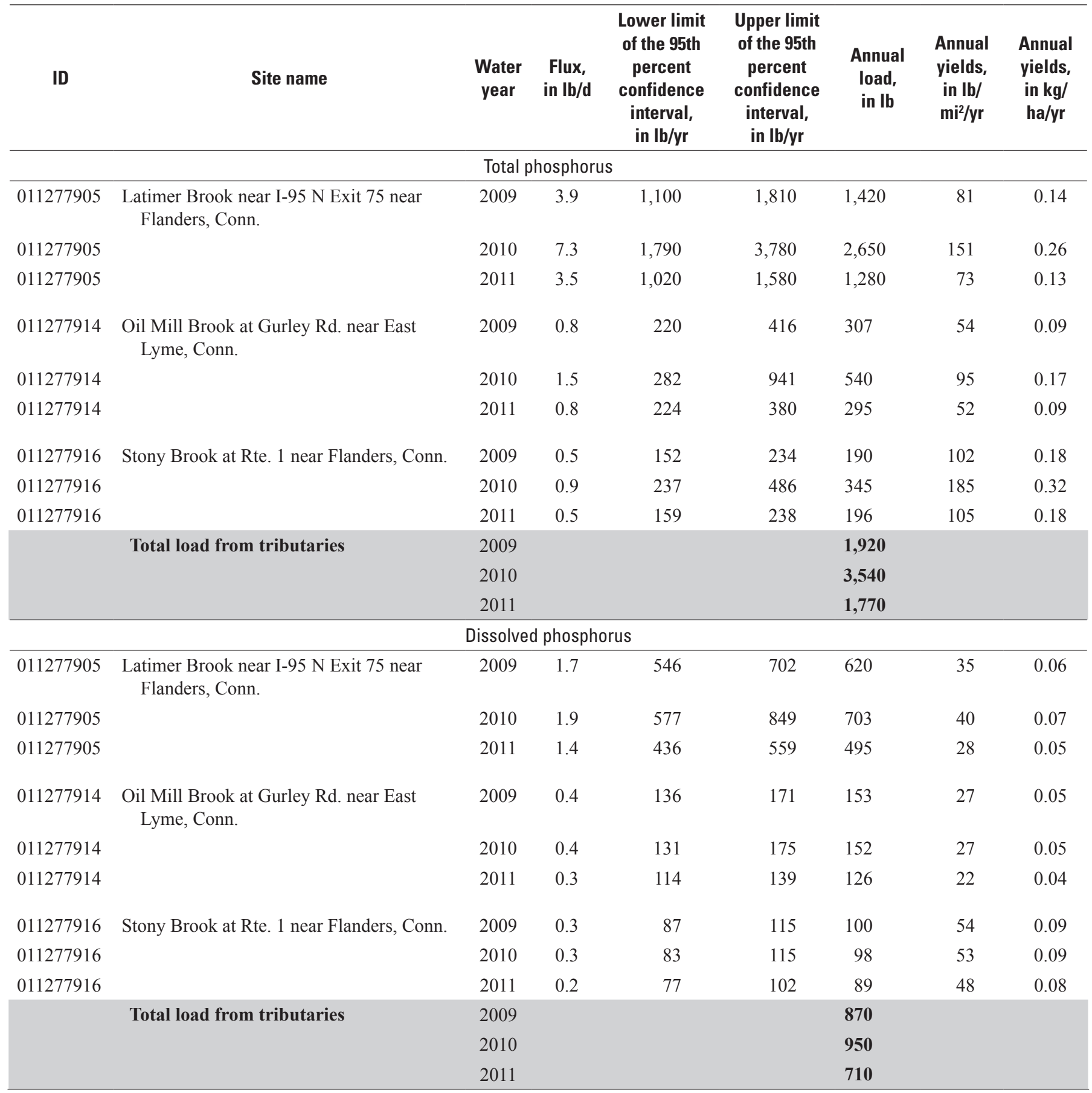




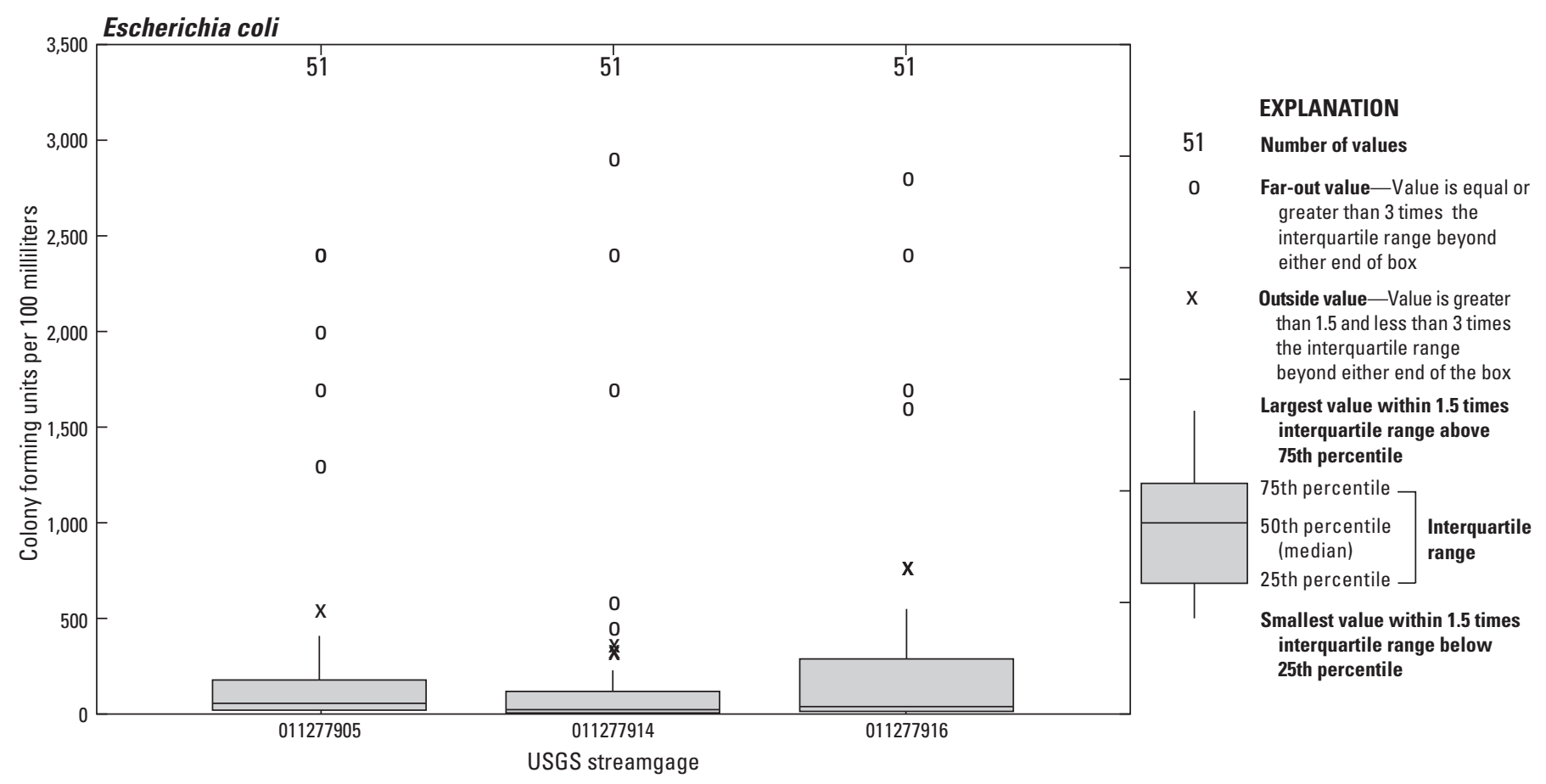

Figure 10. Distribution of Escherichia coli densities in the Niantic River Basin in southeastern Connecticut from August 2008 through February 2012. Data shown are from U.S. Geological Survey (USGS) streamgages 011277905 at Latimer Brook, 011277914 at Oil Mill Brook, and 011277916 at Stony Brook.

with the largest load from the farthest downstream site on Latimer Brook. Nitrogen yields from basin segments were calculated as the difference between downstream and upstream sites divided by the difference in drainage area. Instantaneous total nitrogen yields ranged from 0.02 to 11.2 pounds per square mile per day $\left(\mathrm{lb} / \mathrm{mi}^{2} / \mathrm{d}\right.$; less than 0.01 to 7.2 kilograms per hectare per year $(\mathrm{kg} / \mathrm{ha} / \mathrm{yr}))$. The largest instantaneous yields were measured on the farthest downstream reach of Latimer Brook (between two monitoring stations) and from a small unnamed tributary of the Niantic River that discharges on the southeastern side of the river. The yields measured were generally positively correlated with the percentage of developed land in the drainage area to each reach.

Instantaneous total phosphorus concentrations measured during the base flow survey were generally low, ranging from less than 0.006 to $0.040 \mathrm{mg} / \mathrm{L}$; instantaneous total phosphorus loads ranged from less than 0.010 to $1.20 \mathrm{lb} / \mathrm{d}$.

Beginning in August 2008, streamgages were installed at the downstream end of the three major tributaries of the Niantic River-Latimer Brook, Oil Mill Brook, and Stony Brook. Samples analyzed for nitrogen and phosphorus constituents and for $E$. coli bacteria collected monthly (with additional stormflow samples) from August 2008 to February 2012 were used in the analysis in this report.

The total mean daily flow from all three Niantic River tributaries measured at the streamgages ranged from 25.9 to 37.8 million gallons per day (Mgal/d). The runoff from the Stony Brook site was greater than that from Oil Mill Brook and Latimer Brook likely due to diversions of water for public water supply from the headwaters of these basins. The difference in runoff (converted to streamflow) between Stony Brook and Oil Mill Brook and Latimer Brook combined is equivalent to 7.8 to $10.9 \mathrm{Mgal} / \mathrm{d}$, which is more than the estimated water diversions from the Oil Mill Brook and Latimer Brook Basins. Withdrawal of water from the Niantic River Basin may affect the cycling and delivery of nutrients to the estuary.

Total nitrogen concentrations were generally low at all three tributary monitoring stations, with mean values below the 0.71-mg/L U.S. Environmental Protection Agency (USEPA) recommended nitrogen criterion. Samples from Latimer Brook had higher concentrations of total nitrogen than Oil Mill Brook and Stony Brook, but all concentrations measured were at or less than $1 \mathrm{mg} / \mathrm{L}$. Total ammonia plus organic nitrogen was more than 50 percent of the total nitrogen in samples from Oil Mill Brook and Stony Brook. Organic nitrogen was the dominant species in total ammonia plus organic nitrogen analyses of samples from all three tributaries.

Total nitrogen loads for water years 2009 through 2011 ranged from 41,400 to $60,700 \mathrm{lb}$ combined for all three Niantic River tributaries, with the largest loads during water year 2010. The largest loads were from Latimer Brook and represented 78 to 80 percent of the total nitrogen load from the three tributaries. Loads of total ammonia plus organic nitrogen ranged from 22,000 to $35,600 \mathrm{lb}$ and represented 52 to 60 percent of the total nitrogen load from the three tributaries. The total nitrogen load from Stony Brook was dominated by 

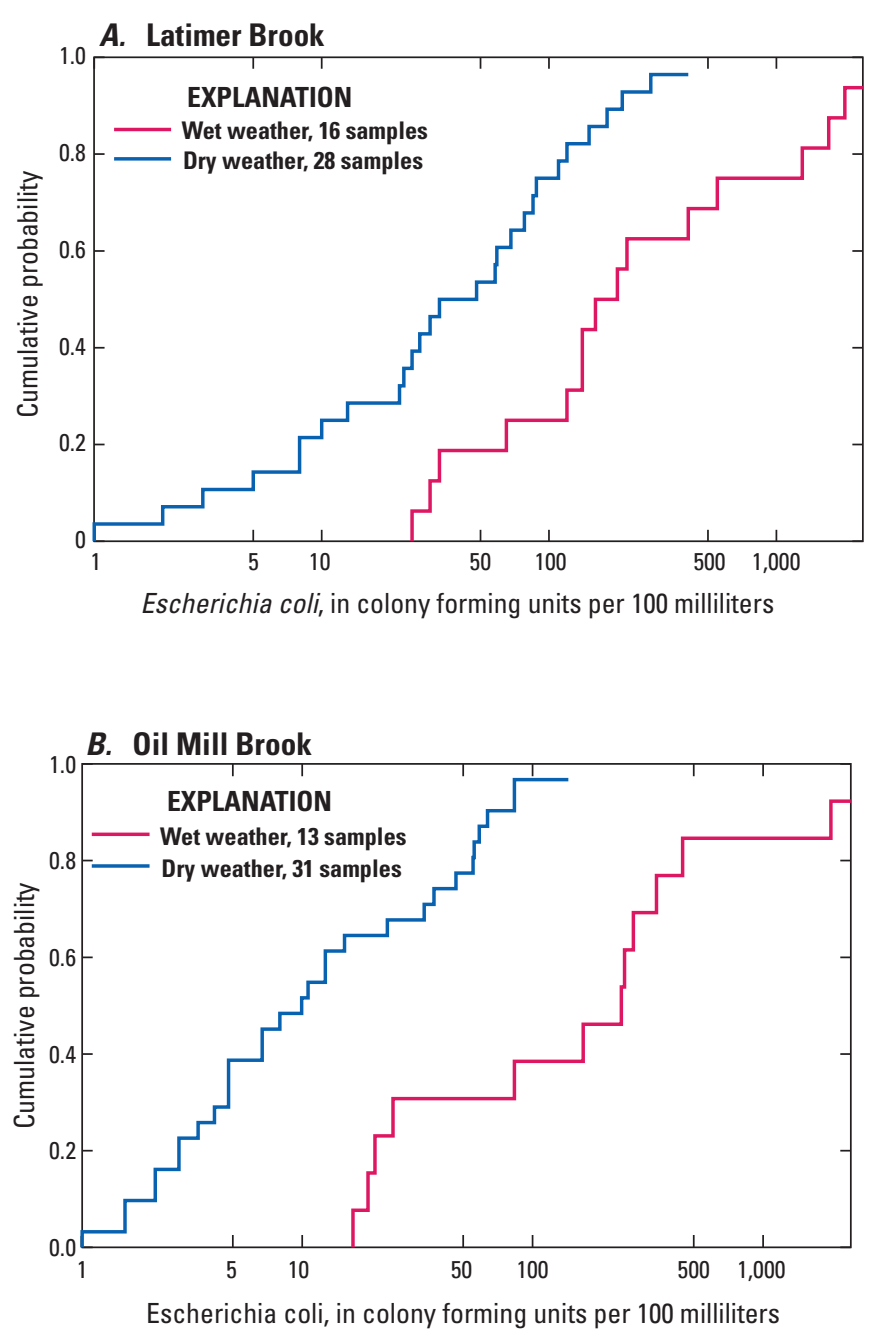

total ammonia plus organic nitrogen. Total nitrogen yields ranged from $1,100 \mathrm{lb} / \mathrm{mi}^{2} / \mathrm{yr}$ at Oil Mill Brook in water year 2011 to $2,720 \mathrm{lb} / \mathrm{mi}^{2} / \mathrm{yr}$ at Latimer Brook in water year 2010 . Total nitrogen yields were generally within the range for other forested basins in New England; Latimer Brook had the highest yields.

Total phosphorus concentrations ranged from less than 0.004 to $0.15 \mathrm{mg} / \mathrm{L}$, and mean concentrations from all three stations were less than the $\mathrm{mg} / \mathrm{L}$ USEPA recommended nutrient criterion for ecoregion XIV. Total phosphorus loads from the three stations totaled 1,770 to 3,540 pounds per year (lb/yr), with yields ranging from 53 to $187 \mathrm{lb} / \mathrm{mi}^{2} / \mathrm{yr}$.

The geometric means of $E$. coli densities in samples from the three Niantic River tributaries were less than State of Connecticut water-quality standards. Single samples from all three stations had densities that exceeded the single-sample maximum values for the State's water-quality standards. An analysis of $E$. coli densities by sample type (wet weather versus base flow) indicated that wet weather (stormflow) samples were more likely to exceed the State's waterquality standards.

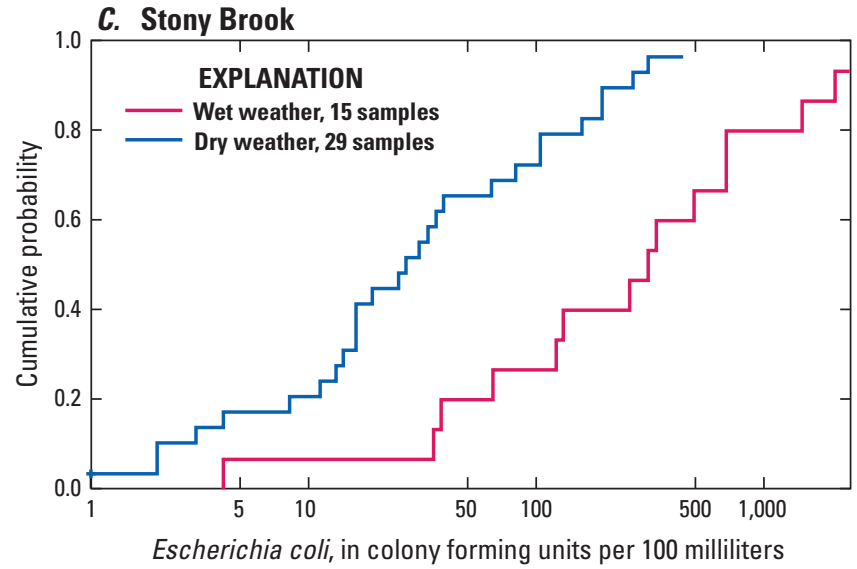

Figure 11. Cumulative probability plots of Escherichia coli densities for dry and wet weather samples from October 2008 through September 2011. Data from U.S. Geological Survey (USGS) streamgages $A, 011277905$ at Latimer Brook, $B$, 011277914 at Oil Mill Brook, and C, 011277916 at Stony Brook are shown.

\section{Selected References}

Cohn, T.A., 1988, Adjusted maximum likelihood estimation of the moments of lognormal populations from type I censored samples: U.S. Geological Survey Open-File Report 88-350, $34 \mathrm{p}$.

Cohn, T.A., Gilroy, E.J., and Baier, W.G., 1992, Estimating fluvial transport of trace constituents using a regression model with data subject to censoring, in Proceedings of the Section on Statistics and the Environment, joint statistical meeting, Boston, August 9-13, 1992: Alexandria, Virginia, American Statistical Association, p. 142-151.

Connecticut Department of Environmental Protection, 2006, Niantic River watershed protection plan: Connecticut Department of Environmental Protection, 180 p., 7 appendixes, accessed at http://www.ct.gov/dep/cwp/ view.asp? $A=2719 \& Q=379296 \#$ nianticriver. 
Connecticut Department of Environmental Protection, 2011a, State of Connecticut integrated water quality report: Hartford, Conn., Connecticut Department of Environmental Protection, 403 p., accessed May 24, 2012, at http://www. ct.gov/dep/lib/dep/water/water_quality_management/305b/ ctiwqr10final.pdf.

Connecticut Department of Environmental Protection, 2011b, Water quality standards: Hartford, Conn., Connecticut Department of Environmental Protection, 65 p., at http:// www.ct.gov/dep/lib/dep/water/water_quality_standards/ wqs_final_adopted_2_25_11.pdf.

Connecticut Department of Public Health and Connecticut Department of Environmental Protection, 2003, Quality assurance project plan for the beach monitoring and notification program for Connecticut Coastal Beaches: Connecticut Department of Public Health and Connecticut Department of Environmental Protection, 23 p., 4 appendixes. [Revised plan available at http://www.ct.gov/ $\mathrm{dep} / \mathrm{lib} / \mathrm{dep} /$ water/beach_monitoring/beach_qapp_11.pdf.]

Coplen, T.B., Böhlke, J.K., and Casciotti, K.L., 2004, Using dual-bacterial denitrification to improve $\delta 15 \mathrm{~N}$ determinations of nitrates containing mass-independent 17O: Rapid Communications in Mass Spectrometry, v. 18, p. $245-250$.

Fishman, M.J., ed., 1993, Methods of analysis by the U.S. Geological Survey National Water Quality LaboratoryDetermination of inorganic and organic constituents in water and fluvial sediments: U.S. Geological Survey OpenFile Report 93-125, 217 p.

Ging, P.B., Lee, R.W., and Silva, S.R., 1996, Water chemistry of Shoal Creek and Waller Creek, Austin, Texas and potential sources of nitrate: U.S. Geological Survey WaterResources Investigations Report 96-4167, 24 p.

Kendall, Carol, 1998, Tracing nitrogen sources and cycling in catchments, chap. 16 of Kendall, Carol, and McDonnell, J.J., eds, Isotope tracers in catchment hydrology: Amsterdam, Elsevier Science B.V., p. 519-576.

Marshall, Nelson, 1994, The scallop estuary-The natural features of the Niantic River: St. Michaels, Maryland, Th'Anchorage Publisher, $152 \mathrm{p}$.

Patton, C.J., and Kryskalla, J.R., 2011, Colorimetric determination of nitrate plus nitrite in water by enzymatic reduction, automated discrete analyzer methods: U.S. Geological Survey Techniques and Methods, book 5, chap. B8, 34 p., at http://pubs.usgs.gov/tm/05b08/.
Patton, C.J., and Truitt, E.P., 2000, Methods of analysis by the U.S. Geological Survey National Water Quality Laboratory-Determination of ammonium plus organic nitrogen by a Kjeldahl digestion method and an automated photometric finish that includes digest cleanup by gas diffusion: U.S. Geological Survey Open-File Report 00-170, $31 \mathrm{p}$.

Rantz, S.E., and others, 1982a, Measurement of stage and discharge, v. 1 of Measurement and computation of streamflow: U.S. Geological Survey Water-Supply Paper 2175, p. 1-284.

Rantz, S.E., and others, 1982b, Computation of discharge, v. 2 of Measurement and computation of streamflow: U.S. Geological Survey Water-Supply Paper 2175, p. 285-631.

Runkel, R.L., Crawford, C.G., Cohn, T.A., 2004, Load estimator (LOADEST) — A Fortran program for estimating constituent loads in streams and rivers: U.S. Geological Survey Techniques and Methods book 4, chap. A5, 69 p., at http://pubs.usgs.gov/tm/2005/tm4A5/.

Rutledge, A.T., 1998, Computer programs for describing the recession of ground-water discharge and for estimating mean ground-water recharge and discharge from streamflow records_Update: U.S. Geological Survey Water-Resources Investigations Report 98-4148, 43 p. [Supersedes U.S. Geological Survey Water-Resources Investigations Report 93-4121.]

Sauer, V.B., and Turnipseed, D.P., 2010, Stage measurement at gaging stations: U.S. Geological Survey Techniques and Methods book 3, chap. A7, 45 p.

Southeastern Connecticut Regional Water Authority, 2012, Supplemental report to the June 2003 southeastern Connecticut regional water supply plan: Southeastern Connecticut Regional Water Authority, 19 p.

Stone, J.R., Schafer, J.P., London, E.H., and Thompson, W.B., 1992, Surficial materials map of Connecticut: U.S. Geological Special Map, scale 1:125,000, 2 sheets.

Thomas, M.P., 1966, Effect of glacial geology upon the time distribution of streamflow in eastern and southern Connecticut, in Geological Survey research 1966: U.S. Geological Survey Professional Paper 550-B, p. B209B212.

Trench, E.C.T., 2000, Nutrient sources and loads in the Connecticut, Housatonic, and Thames River Basins: U.S. Geological Survey Water-Resources Investigations Report 99-4236, 66 p. 
Turnipseed, D.P., and Sauer, V.B., 2010, Discharge measurements at gaging stations: U.S. Geological Survey Techniques and Methods book 3, chap. A8, 87 p.

U.S. Census Bureau, 2012, Census block shapefiles with 2010 census population and housing unit counts Web site, accessed November 13, 2012, at http://www.census.gov/ geo/www/tiger/tgrshp2010/pophu.html.

U.S. Environmental Protection Agency, State of Connecticut, State of New York, Interstate Sanitation Commission, and National Oceanic and Atmospheric Administration, 1985, Long Island Sound estuarine study, water quality management strategy: $10 \mathrm{p}$.

U.S. Environmental Protection Agency, 1993, Determination of phosphorus by semi-automated colorimetry (revision 2.0), method 365.1 of Methods for the determination of inorganic substances in environmental samples: U.S. Environmental Protection Agency EPA/600/R-93/100, p. 365.1-1-365.1-17.

U.S. Environmental Protection Agency, 2000, Ambient water quality criteria recommendations - Information supporting the development of state and tribal nutrient criteria; rivers and streams in nutrient ecoregion XIV: U.S. Environmental Protection Agency EPA 822-B-00-022, 84 p.

University of Connecticut, 2009, 2006 land use land cover dataset: University of Connecticut, Center for Land Use Education and Research, Connecticut's Changing Landscape Web site, accessed November 27, 2012 at http:// clear.uconn.edu/projects/landscape/download.asp.
Vaudrey, J.P., 2008, Establishing restoration objectives for eelgrass in Long Island Sound; Part II—Case studies: Groton, Conn., University of Connecticut FRS\#542190, $59 \mathrm{p}$.

Wilde F.D., and Radtke, D.B., 1998, Field measurements: U.S. Geological Survey Techniques of Water-Resources Investigations, book 9, chap. A6, [variously paged].

Wilde, F.D., Radtke, D.B., Gibs, Jacob, and Iwatsubo, R.T., 1998a, Cleaning of equipment for water sampling: U.S. Geological Survey Techniques of Water-Resources Investigations, book 9, chap. A3, [variously paged].

Wilde, F.D., Radtke, D.B., Gibs, Jacob, and Iwatsubo, R.T., 1998b, Preparations for water sampling: U.S. Geological Survey Techniques of Water-Resources Investigations, book 9 , chap. A1, [variously paged].

Wilde, F.D., Radtke, D.B., Gibs, Jacob, and Iwatsubo, R.T., 1998c, Selection of equipment for water sampling: U.S. Geological Survey Techniques of Water-Resources Investigations, book 9, chap. A2, [variously paged].

Wilde, F.D., Radtke, D.B., Gibs, Jacob, and Iwatsubo, R.T., 1999a, Collection of water samples: U.S. Geological Survey Techniques of Water- Resources Investigations, book 9, chap. A4, [variously paged].

Wilde, F.D., Radtke, D.B., Gibs, Jacob, and Iwatsubo, R.T., 1999b, Processing of water samples: U.S. Geological Survey Techniques of Water-Resources Investigations, book 9, chap. A5, [variously paged]. 
This page has been left blank intentionally. 
Prepared by the Pembroke Publishing Service Center.

For more information concerning this report, contact:

Office Chief

U.S. Geological Survey

New England Water Science Center

Connecticut Water Science Office

101 Pitkin Street

East Hartford, CT 06108

dc_ct@usgs.gov

or visit our Web site at:

http://ct.water.usgs.gov 
㺃 